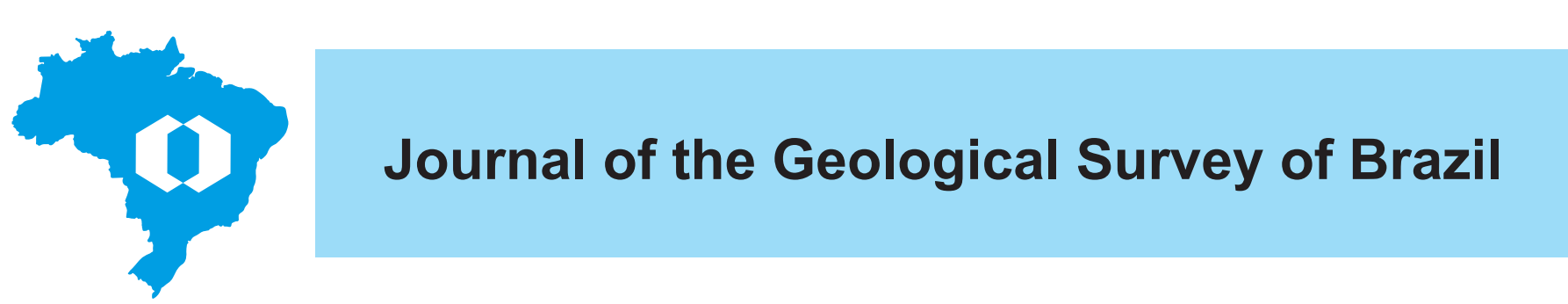

\title{
Geological knowledge advances on the Alto Rio Negro region, northwestern Amazonian Craton, Brazil: a review
}

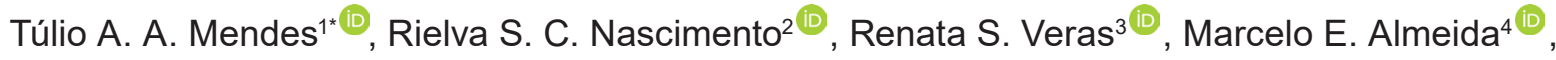 \\ Luiz G. Knauer ${ }^{5}$ (D) \\ ${ }^{1}$ Geological Survey of Brazil, CPRM-SUREG-MA, Manaus 69067-375, Brazil. \\ ${ }^{2}$ Federal University of Amazonas (UFAM), Department of Geosciences, Manaus 69077-000, Brazil. \\ ${ }^{3}$ Federal University of Pará (UFPA), Geology and Geochemistry Postgraduate Program - Institute of Geosciences, Belém 66075-110, Brazil. \\ ${ }^{4}$ Geological Survey of Brazil, CPRM-ERJ, Rio de Janeiro 22290-255, Brazil. \\ ${ }^{5}$ Federal University of Minas Gerais (UFMG), Geology Department - Institute of Geosciences, CPMTC-IGC, Belo Horizonte 31270-901, Brazil.
}

\section{Abstract}

This paper presents a literature review of the geology of the Alto Rio Negro region, located in northwestern Brazil. Firstly, we summarize the Amazonian Craton tectonic models and how the study area fits in these different tectonic models. The aim is to organize the literature data and better guide the consultation for new studies. The first geological reports about the Alto Rio Negro are from the Mid-19th century, when the British naturalist Alfred Russel Wallace travels to this country and, since then, long periods of scientific production absence occur. However, after the RADAMBRASIL Project in the 1970s, there was a significant research advance. Recent publications reveal a complex tectonic evolution, with three events that mark periods of generation and reworking of the Proterozoic basement. Two Paleoproterozoic magmatic arc systems generated the geological basement. The Calymmian collision of these terrains produced a large volume of crustal granites, in addition to pre-, and post-tectonic granites. A crustal reworking period $(1.4-1.1 \mathrm{Ga})$ reactivated the basement structures and, possibly, generated the Ectasian carbonatitic intrusions. There are many difficulties to access this region, so the literature data are of great value and provide a background for new studies. The lack of more detailed geological maps covering the Alto Rio Negro region is the main obstacle. Still, it offers a fertile research field for geologists interested in contributing to diverse research fields of Geology focusing on the Amazonian Craton.

\section{Article Information}

Publication type: Review Articles Received 29 June 2021

Accepted 19 October 2021

Online pub. 5 November 2021

Editor: Fabricio Caxito

\section{Keywords:}

Alto Rio Negro,

Amazonian Craton,

Precambrian,

Geochronological provinces,

Guiana Shield

${ }^{*}$ Corresponding author

Túlio A. A. Mendes

Túlio A. A. Mendes
tulio.mendes@cprm.gov.br

\section{Introduction}

The Amazon is a territory with a continental dimension, covered by a dense equatorial forest where there are relatively low human occupation and few access roads, making field research activities difficult. Notwithstanding the imponderable environmental damage, anthropogenic activities advancement (e.g. agriculture, mining, and settlement around highways) has facilitated mapping and geological research. However, in more remote areas, geological knowledge is still at an embryonic level (e.g. Alto Rio Negro - Amazonas state, Iriri-Xingu region - Pará state, and Tumucumaque - Amapá state).

The first geological data of the Amazon date from the Mid19th century (Wallace 1853). On this occasion, the naturalist Alfred Russel Wallace carried out a pioneering expedition that reached the Alto Rio Negro region, the focus area of this review article. However, a more comprehensive geological recognition of this area dates from the 1970s, when the Brazilian government yielded remote sensing images and funded small-scale mapping (RADAMBRASIL Project).

In the past two decades, the Geological Survey of Brazil (SGB/CPRM) conducted several mapping projects in the Amazonian Craton. The broad overlapping of demarcated indigenous territories also implies several restrictions on mineral exploration activities, making the area economically uninteresting. Nevertheless, some recent publications concerning the Alto Rio Negro region have provided significant advances, mainly in petrology, geochronology, and tectonics.

This literature review paper will unravel geological knowledge evolution in the Alto Rio Negro region, starting from the first expedition in the 19th century to the most recent research, consolidated until 2021. Despite the geological framework's 
continuity to southern Colombia and Venezuela, this work comprises only Brazilian data, considering the significant difference in knowledge stage and geological nomenclature.

\section{Geochronological Provinces of the Amazonian Craton: Rio Negro-Juruena versus Rio Negro}

The Brazilian territory comprises a large part of the South American Platform, in which Phanerozoic covers and Precambrian shields stand out (Almeida 1981). The areas with basement exposure are the Central Brazil and Guiana shields that form the Amazonian Craton, comprehending vast areas of Brazil, Bolivia, Colombia, Venezuela, Guyana, Suriname, and French Guiana. The Alto Rio Negro region fits in the northwestern portion of this craton (Figure 1A).

Amaral (1974) provided the first isotopic data for the Amazon region. The author admits an essentially fixist tectonic vision, considering the Amazonian Craton as an Archean continental mass affected by several Proterozoic reworking episodes and crustal rejuvenation. This author proposed the first subdivision of the craton into three provinces, elongated in an approximately $\mathrm{N}-\mathrm{S}$ direction, which show more significant rejuvenation to the west. Hasui et al. (1984) also follow a fixist concept, although the authors interpret the craton as a mosaic of several crustal blocks or paleoplates limited by mobile belts (high-grade granulitic terrains) with preferential NE-SW and NW-SE directions.

However, most of the studies that followed consider a mobilist paradigm and have proposed new geotectonic models or adjustments to previous models. Among the most recent versions, and on which there is still an intense debate by the geological community, are the models proposed by Cordani and Teixeira (2007) (Figure 1B) and Santos et al. (2006) (Figure 1C). Based on the maps presented by these tectonic models, the Alto Rio Negro region fits in the Rio NegroJuruena Province (1.78-1.55 Ga) or the Rio Negro Province (1.82-1.52 Ga), respectively according to the previous works.

Cordani and Teixeira (2007) used isotopic data and structural similarities to define the provinces and, in general terms, converge to other previous models. According to a set of similar proposals (Cordani et al. 1979; Teixeira et al. 1989; Tassinari 1996; Tassinari and Macambira 1999, 2004; Cordani and Teixeira 2007), the Rio Negro-Juruena Province is a mobile belt with NW-SE trend, which extends from the

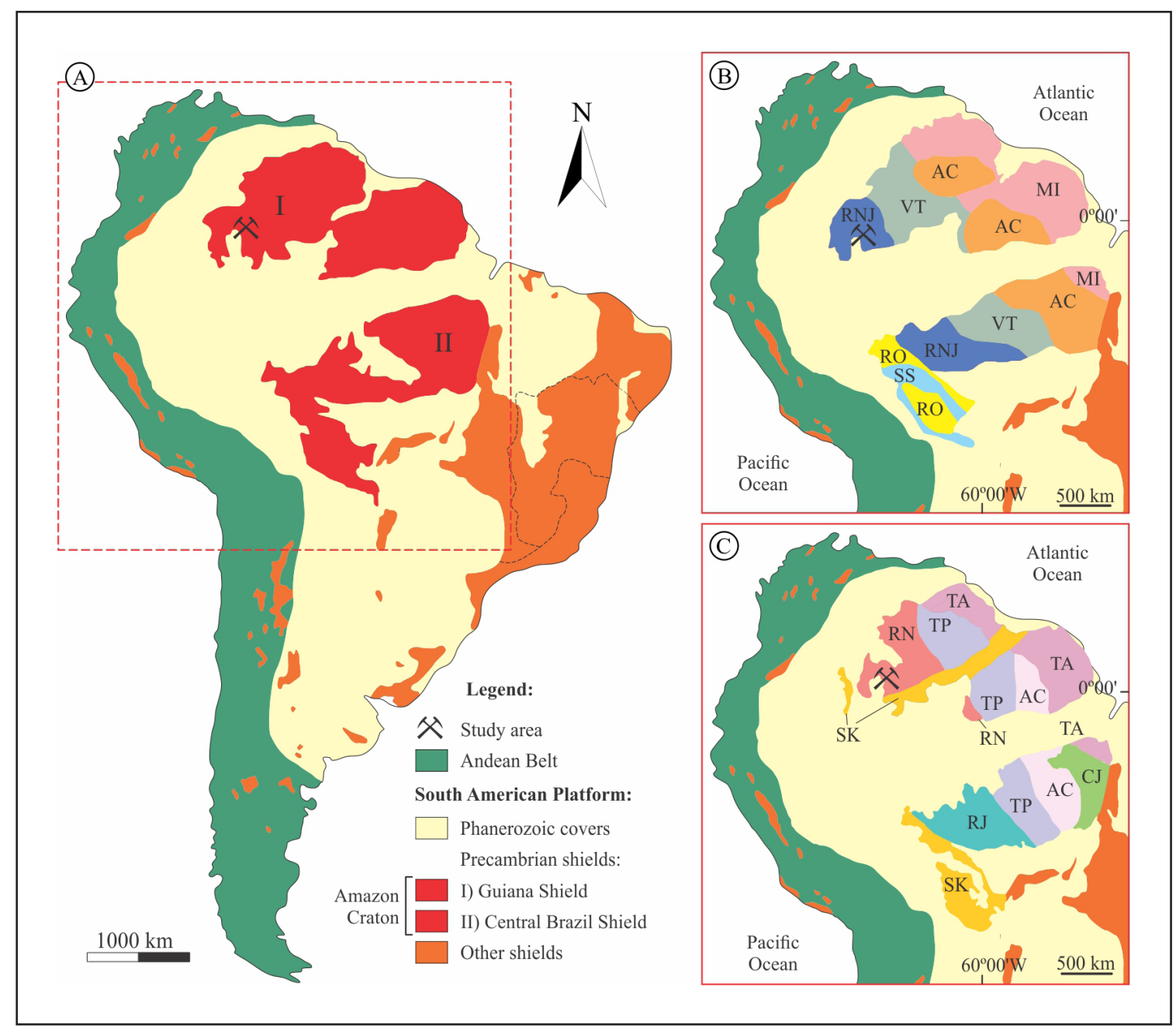

FIGURE 1. Tectonic compartmentalization of South America and the Amazonian Craton. (A) South America tectonic compartmentation modified of Almeida (1981). Amazonian Craton Geochronological provinces according to the proposals of (B) Cordani and Teixeira (2007): CA - Central Amazonian (> 2.60 Ga), MI - Maroni-Itacaiúnas (2.25-2, $05 \mathrm{Ga})$, VT - Ventuari-Tapajós (1.98-1.81 Ga), RNJ - Rio Negro-Juruena (1.78-1.55 $\mathrm{Ga}), \mathrm{RO}$ - Rondonian-San Ignacio (1.55-1.30 Ga), and SS - Sunsás-Aguapeí (1.25-1.00 Ga); and (C) Santos et al. (2006, 2008): CJ - Carajás (3.00-2.50 Ga), TA - Transamazon (2.26-2.01 Ga), TP - Tapajós-Parima (2.03-1.88 Ga), RN - Rio Negro (1.82-1.52 Ga), RJ - Rondônia-Juruena (1.82-1.54 Ga), and SK - Sunsás and K'Mudku (1.45-1.10 Ga). 
northwest to the southwest of the craton, and is characterized by the abundance of granitoids aged in the 1.78-1.55 Ga interval. It is noteworthy that most of the data was produced by the Rb-Sr and K-Ar methods (Cordani and Teixeira 2007), which may imply a lack of robustness in terms of the interpreted ages (Santos et al. 2008).

In opposition to these models, Santos et al. (2000, 2006, 2008) highlight differences between the Rio Negro and Juruena domains. These authors propose the separation of the Rio Negro-Juruena Province, treating the Rio Negro region as a separate province and limited to the Guiana Shield. According to Santos et al. (2000), the U-Pb geochronological data support evolution in different geological times, the northern province (Rio Negro; 1.86-1.52 Ga) being slightly older than its southern counterpart (Rondônia-Juruena; 1.76 $1.47 \mathrm{Ga}$ ). They also claim that, while the Rondônia-Juruena Province has a main structural WNW-ESE to E-W trend, the Rio Negro Province does not present a dominant trend, with a polyphasic tectono-metamorphic evolution, and with few preserved supracrustal rocks. Santos et al. (2008) also highlight the K'Mudku Intracontinental Orogen, a Grenvillean aged belt $(\sim 1.4-1.1 \mathrm{Ga})$ that crosses the Guiana Shield as a tectonic reflex of the Sunsás Orogeny.

\section{First reports to the regional geological recognition (RADAMBRASIL Project): the Alto Rio Negro on the map}

The naturalist Alfred R. Wallace was a pioneer scientist to explore the Amazonia and, at the beginning of his geological reports (Wallace 1853), he describes the difficulties in understanding the regional geology, especially after the loss of his samples in a shipwreck during the return to Great Britain. Nevertheless, the first observations on the geomorphology, lithotypes, structures, and field relations of the Alto Rio Negro region were made by him. The author narrates his perplexity at such a vast and flat terrain, but with numerous peaks, as described: "slender pillars of rock rise above the surrounding forest like dead trunks of giant trees" that "spring up abruptly, as if elevated by some local isolated force" (Wallace 1853).

Wallace described the predominance of granitic rocks (Figure 2A) with little mica, granite dikes, and quartz veins, generally with east-west-trending direction. He also measured an isolated outcrop of coarse sandstone and possible gneiss, whose structures plunge sub-vertically southwards (Figure 2B). According to Wallace (1853), the Andean belt and the Amazon magmatic rocks' generation coincide with valleys and plains' sedimentary filling. Simultaneous volcanism and sedimentation in an underwater environment are suggested as the mechanism for forming peaks and plains, respectively.

The field trip made by Glycon Paiva in 1928, the first specifically dedicated to geologic recognition, was organized by the ancient Geological and Mineralogical Service of Brazil. Paiva (1929) reports the predominance of granitoids, a wide recent sedimentary cover, and also added the description of metasedimentary rocks in the Tunuí mountain range and outcrops in the Aiari River's channel. The next references in the literature would come after about 40 years (Giffoni and Abrahão 1969 apud Pinheiro et al. 1976; Abrahão and Alecrim 1969 apud Pinheiro et al. 1976).

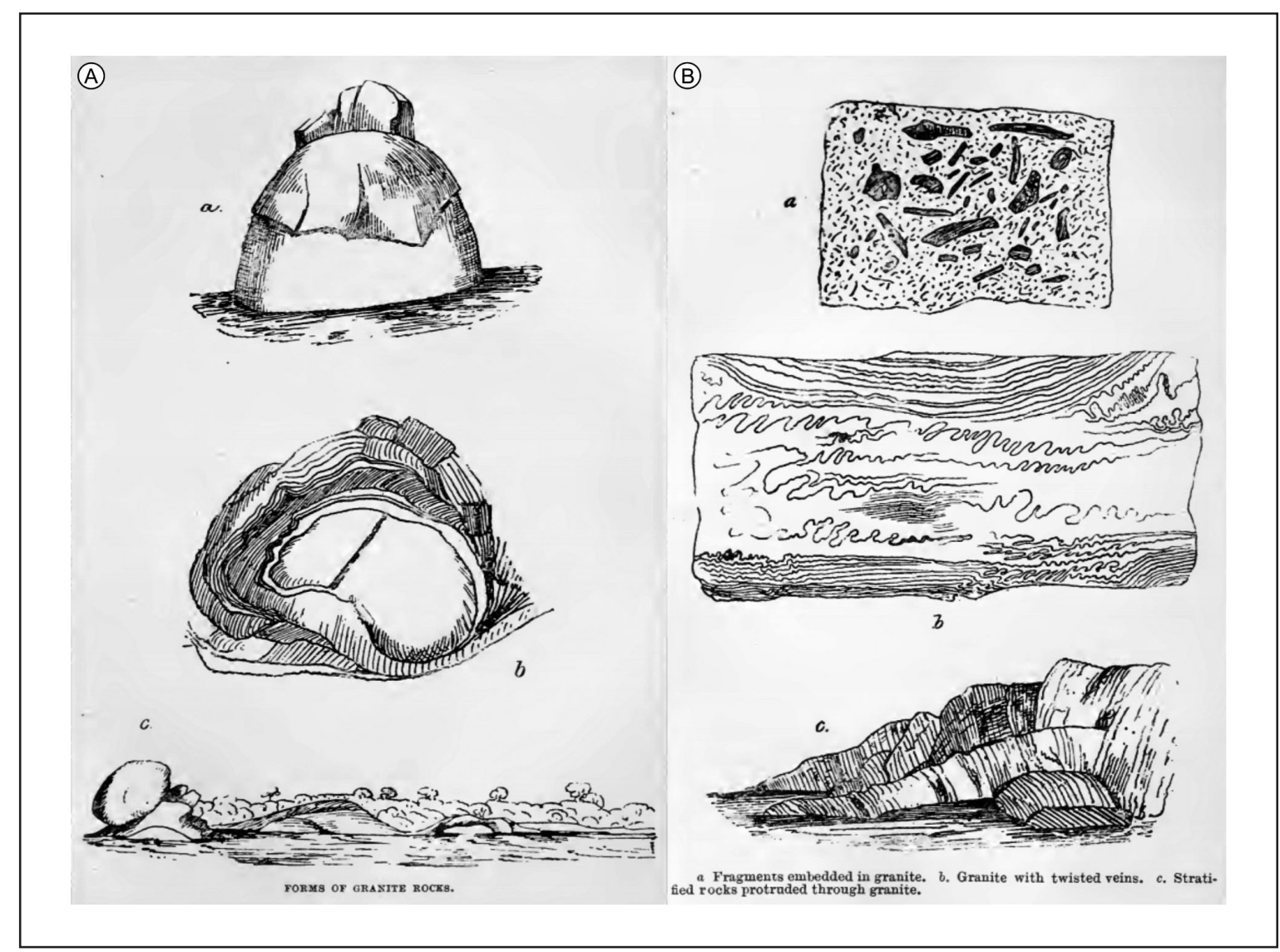

FIGURE 2. Field features sketches of the Alto Rio Negro region made by Alfred R. Wallace (Wallace 1853). (A) Outcrop sketch; and (B) magmatic and structural features of the rocks. 
In the RADAMBRASIL scope, a series of geological recognition projects (Montalvão et al. 1975; Pinheiro et al. 1976; Dall'Agnol and Abreu 1976; Fernandes et al. 1977; Lourenço et al. 1978) performed the mapping and set a lithostratigraphy organization for the region (Figure 3). According to the lexicon of the time, the following geological units have been established: Guianense Complex (biotite granites, biotite-hornblende granites, biotite-muscovite granites, migmatites, and gneisses - "Lower to Medium Precambrian"); Tunuí Group (quartzites, itabirites, and phyllites with greenschist facies metamorphic conditions "Medium to Upper Precambrian"); Tiquié Granite (intrusive granitic bodies in the Guianense Complex - "Medium to Upper Precambrian"); sedimentary covers of the Roraima Group (corresponding to the mountains near the Venezuela border, such as the Neblina and Aracá ranges - "Upper Precambrian"); in addition to the Seis Lagos Carbonatite ("Upper Paleozoic to Mesozoic") and recent covers ("Quaternary").

Lima and Pires (1985) reassessed the RADAMBRASIL data, in addition to other contributions including works in neighboring countries (CODESUR 1973 apud Lima and Pires 1985; Galvis et al. 1979 apud Lima and Pires 1985; Tassinari 1981), and proposed a new lithostratigraphy and a geological sketch for the Alto Rio Negro region (Figure 4A). Although without a significant advance concerning field data and with limited analytical techniques (e.g. crystallization age determined by $\mathrm{Rb}-\mathrm{Sr}$ isotopic data), this work shows progress in individualizing new geological units and tectonic implications. The geological sketch presented by Lima and Pires (1985) includes: A) the Rio Parima, Rio Negro, and Traíras complexes compose the northern sector of the Parima-Tapajós belt $(2.60-2.00 \mathrm{Ga})$; B) the Serra do
Curupira Intrusive Suite includes post-tectonic granitoids; C) the Cauaburi Complex represents the reworking product of the Rio Negro Complex during the Central Guiana orogeny $(1.90-1.80 \mathrm{Ga}) ; \mathrm{D})$ the Curicuriari Intrusive Suite gathers collisional plutonism of the Rio Negro-Juruena belt (1.75$1.60 \mathrm{Ga}$ ); E) deposition of psamo-pelitic sediments occurs and, after another collision, the metamorphic rocks of the Uaupés Complex and collisional granitoids of the Rio Içana Intrusive Suite were generated; F) supracrustal successions previously attributed to the Tunuí Group were assigned to the Roraima Group that was deposited in a tectonic quiescence period and associated with basic magmatism (Tapuruquara Intrusive Suite); G) the Cachimbo-Traíra belt (1.55-1.45 Ga) was responsible for the deformation of the discontinuous exposures of the Roraima Group; $\mathrm{H}$ ) at the end of this last collision, the emplacement of late- to postorogenic granitoids from the Tiquié Intrusive Suite occurs; I) Mesozoic rifting, correlated to the Tacutu Graben, generated the alkaline rocks of the Seis Lagos Intrusive Suite.

In the early 1990s, the Alto Rio Negro Project aimed to map selected areas of the region on a 1:100.000 scale, but switched to regional integration (1:500.000 scale). The results are disclosed in an internal preliminary report (Melo and Villas Boas 1993) and conference abstracts in scientific events (Melo and Villas Boas 1994; Melo et al. 1996). These authors present two geotectonic domains: Caparro Terrain, located in the western portion; and the "Central Guiana Belt", covering the central-eastern portion (Figure 4B).

The Caparro Terrain (Neoarchean to Paleoproterozoic) comprises: A) the Traíras Complex (foliated granitoids associated with migmatites); B) the Tunuí Group (metasedimentary and acidic volcanic rocks); C) the Xié Suite (biotite granite with titanite and two mica granites).

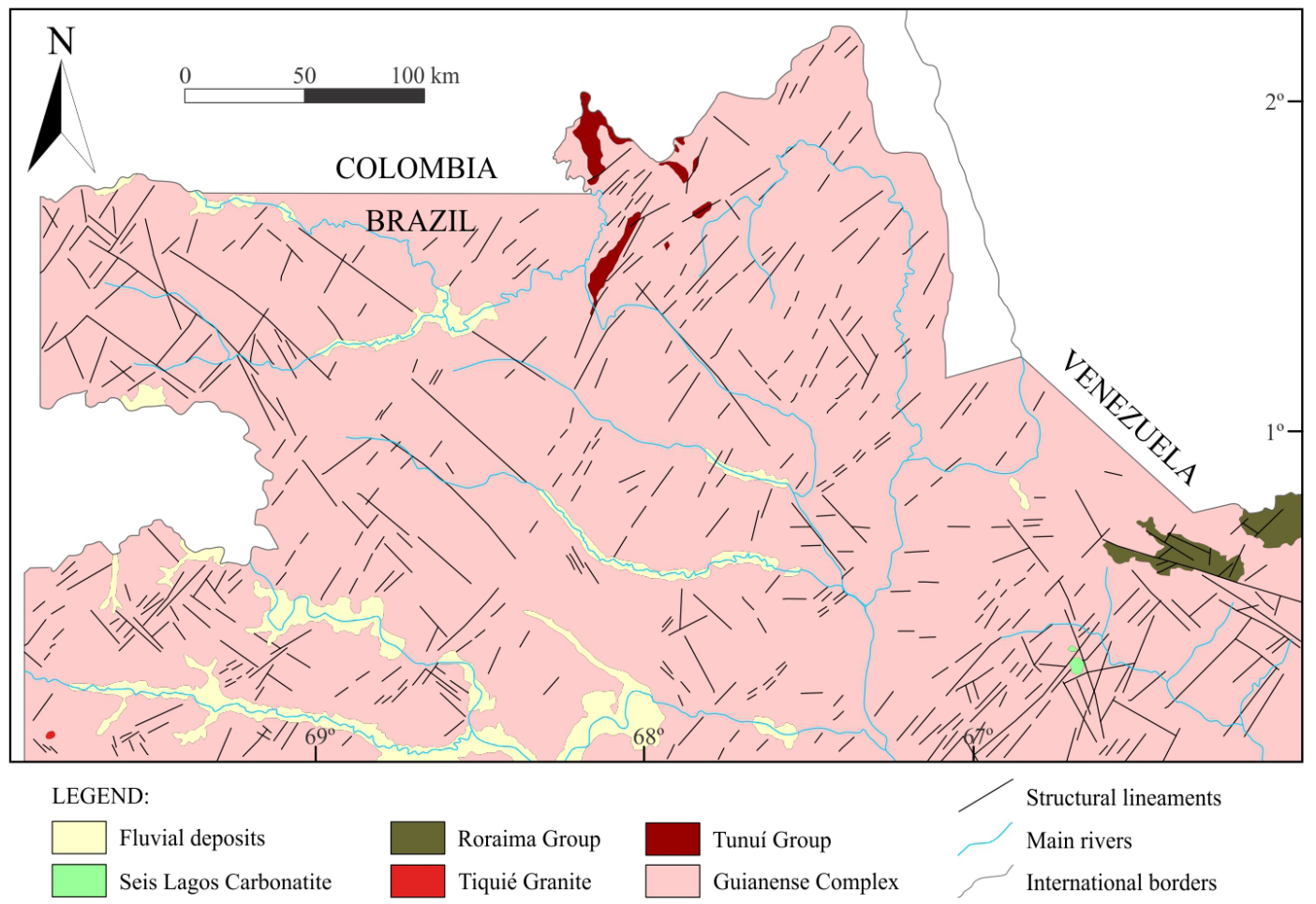

FIGURE 3. First geological map of the Alto Rio Negro region, modified from Pinheiro et al. (1976). 
The Central Guiana Belt Domain comprises: A) the Cauaburi Complex (mylonitic granite from the Neoarchean to Paleoproterozoic); B) the Daraá Group, with quartzites and tuffs of the Aracá and Daraá ranges (Neoarchean to Paleoproterozoic); C) syn- to late-collisional granites of the Marauiá Granite (Neoarchean to Paleoproterozoic); D) metasedimentary successions of the Padre and Neblina ranges, grouped in the Roraima Supergroup (Mesoproterozoic); E) anorogenic granitoids from the Tiquié Suite (Mesoproterozoic); F) dikes of the Cujubim and Uaraná diabases, and G) the Seis Lagos Alkaline Complex (Mesozoic).

\section{Lithostratigraphy: geological state-of-the-art}

In the last decade, the UFAM postgraduate program carried out most of the research field campaigns in the Alto Rio Negro
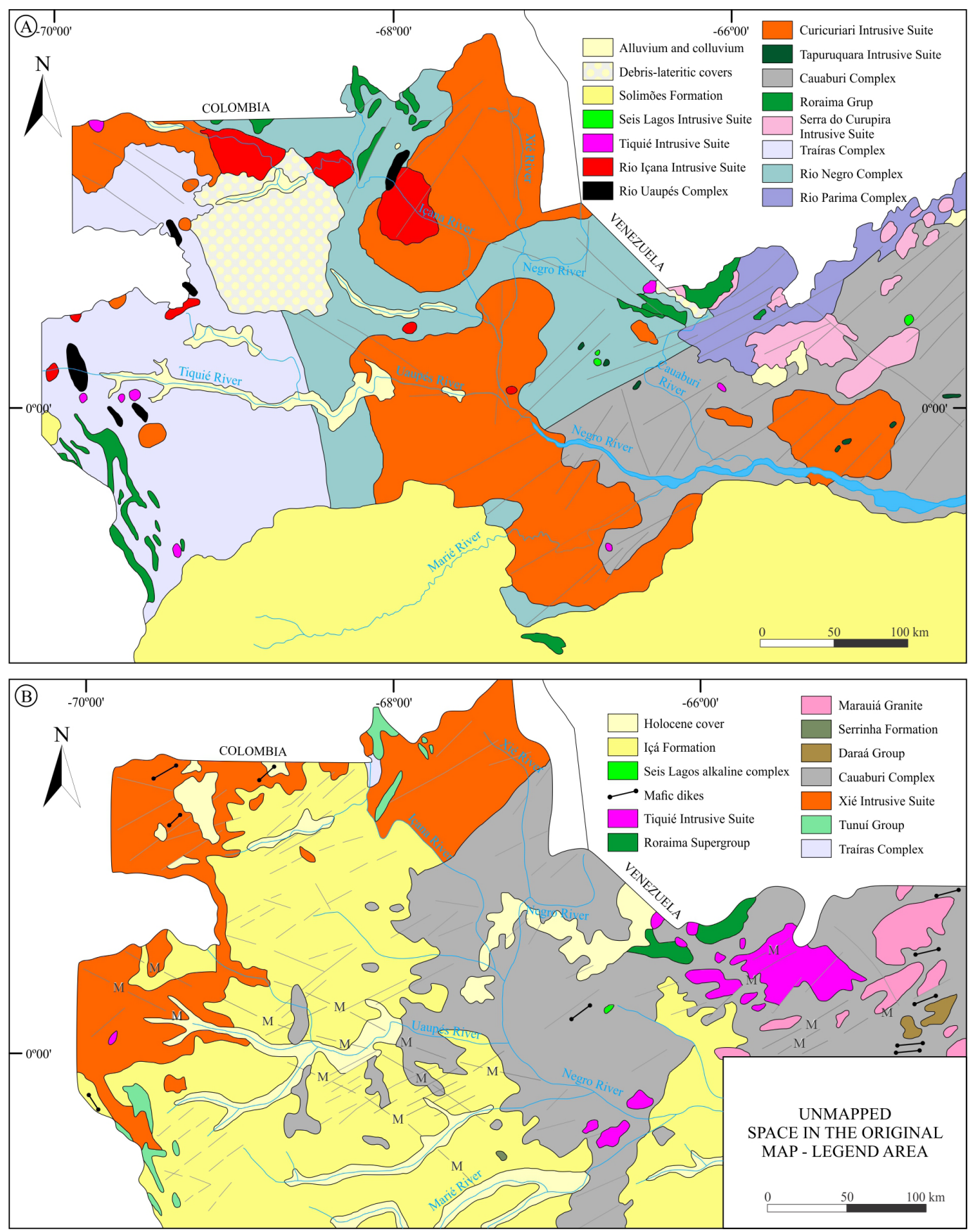

FIGURE 4. First geological maps of the Alto Rio Negro region. (A) Geological sketch of the Alto Rio Negro region, modified from Lima and Pires (1985), based RADAMBRASIL Project data. (B) Preliminary geological map of the Alto Rio Negro Project (unfinished project), modified by Melo et al. (1996). Grayish lines correspond to photointerpreted morphostructural lineaments; dashed lines (with the interspersed letter "M") correspond to magnetic lineaments (aerial survey obtained with two kilometers spacing; Hilderbrand et al. 1988). 
region (Souza 2009; Veras 2012; Rodrigues 2016; Carneiro 2016; Gomes 2018).. These works focused mainly on the basement rocks and brought new structural, petrographic, chemical, and isotopic data (Carneiro et al. 2017; Veras et al. 2018; Gomes et al. 2021). Recently, the Geological Service of Brazil published a multi-focused project (Projeto Terras Indígenas do Noroeste do Amazonas: geologia, geoquímica e cadastramento mineral na região do Tunuí-Caparro Andretta 2020), presenting the geological map of part of the Alto Rio Negro (Mendes et al. 2020) that yielded the current stage of the lithostratigraphic nomenclature. These research works allowed us to redefine the Alto Rio Negro cartography (Figure 5) and, here, we present a compilation with the main characteristics of the geological units. The collection of geochronological data for the Rio Negro Province (i.e. Santos et al. 2006) is exhibited in Table 1.

\subsection{Paleoproterozoic basement}

\subsubsection{Cauaburi Complex}

The Cauaburi Complex represents the basement of the Imeri Domain and crops out along the Negro, Cauaburi, Curicuriari, and Uaupés rivers, besides the lower Içana River (Figure 5). This geological unit is composed of Orosirian-Statherian orthogneisses and metagranitoids and, despite lithological variations (i.e. texture, chemical, and mineralogical compositions), records the same deformational and metamorphic pattern (Carneiro et al. 2017). Based on the textural aspects, Almeida et al. (2002) subdivided the Cauaburi Complex into the Tarsira and Santa Izabel do Rio Negro facies (Almeida 2006). Carneiro et al. (2017) present field, petrographic, and mineral and whole-rock chemical data of the basement rocks that crop out between the São Gabriel da Cachoeira and Santa Izabel do Rio Negro cities, adding to the Cauaburi Complex two new facies, named as São Jorge and Cumati (Figure 5), this last one considered as a new complex by Almeida (2006).

The Tarsira Facies comprises biotite augen-gneiss and metamonzogranites, commonly presenting ovoid feldspar phenocrysts reaching ca. $8 \mathrm{~cm}$ in length (Almeida et al. 2002, 2013; Melo and Villas Boas 1993; Rodrigues 2016). The Santa Izabel do Rio Negro facies gathers biotite-(hornblende) gneisses and metagranitoids with porphyritic texture and composition ranging from monzogranitic to tonalitic (Almeida et al. 2002; Carneiro et al. 2017). These are metaluminous rocks with a medium- to high-K calc-alkaline chemical affinity (Brito et al. 2000; Carneiro et al. 2017). Recent works (Veras et al. 2018; Mendes et al. 2021) present the occurrence of Cauaburi Complex metagranitoids related to the Santa Izabel Facies of the Rio Negro in the northwestern area (Içana Domain - Figure 5). The age range for crystallization of the Santa Izabel do Rio Negro facies is between $1828 \pm 9 \mathrm{Ma}$ (U-Pb in zircon; Rossoni et al. 2017) and $1754 \pm 7 \mathrm{Ma}$ (U-Pb in zircon; Mendes et al. 2021). Veras et al. (2019) present a metamorphic age at $1530 \pm 7 \mathrm{Ma}$ related to the Içana Orogeny (Calymmian collision). Mendes et al. (2021) bring geochronological data (U-Pb in zircon) that revealed the zircon crystallization age dispersion (1805 to 1754 Ma; Table 1) in the western Cauaburi Complex metagranitoids, which is related to the record of multiple incremental pulses in a dynamic magma chamber. The isotopic dataset reveals Sm$\mathrm{Nd}$ model ages in the 2.40-1.99 $\mathrm{Ga}$ interval and $\varepsilon \mathrm{Nd}$ values between +0.78 and -2.24 (Almeida et al. 2013).

The Cumati Facies (previously named Cumati Complex; Almeida et al. 2013) consists of tonalitic and granodioritic finegrained orthogneisses, with calc-alkaline chemical affinity and

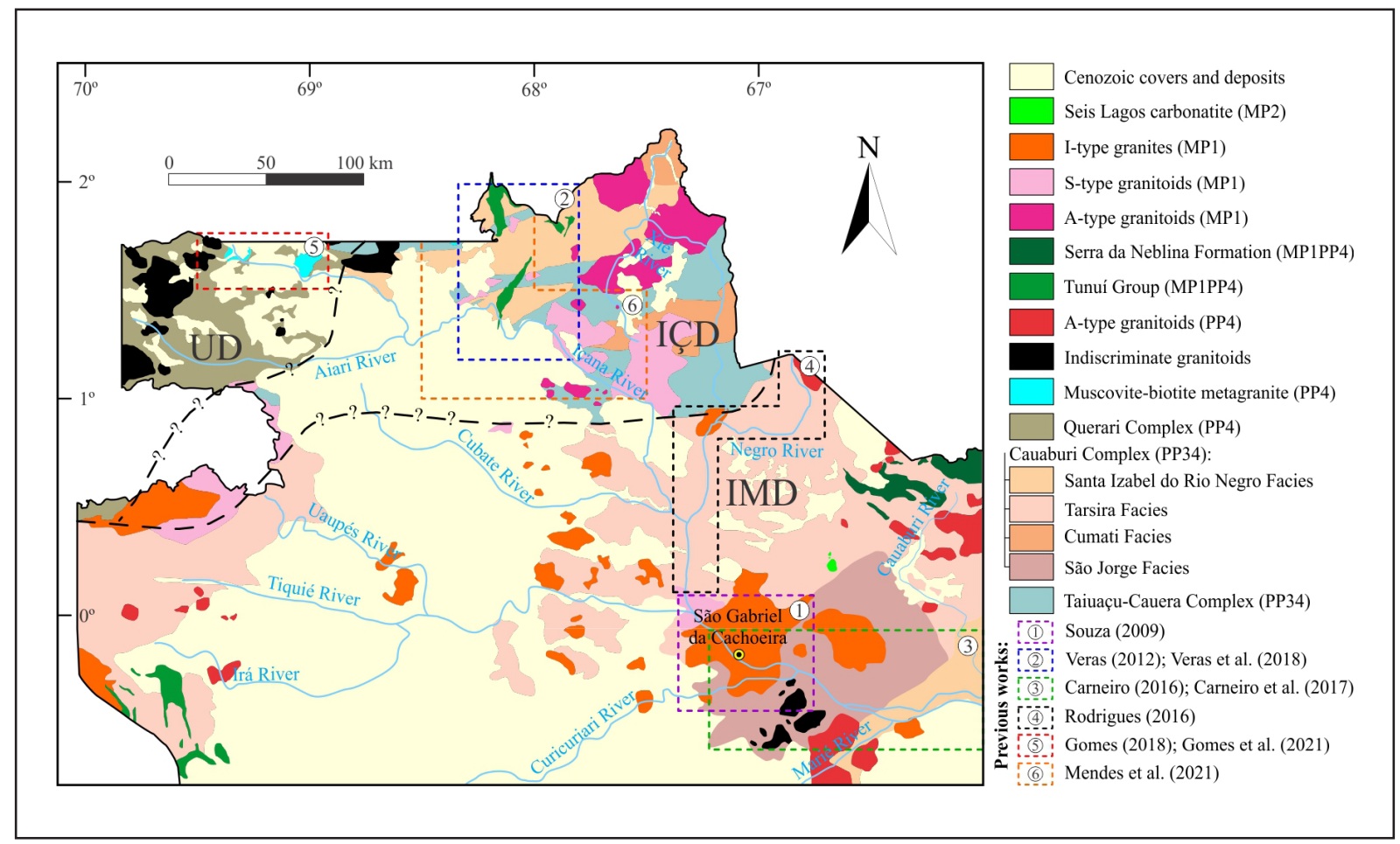

FIGURE 5. Geological map of the Alto Rio Negro region (current conception), based in Almeida (2006), Almeida et al. (2013), Carneiro et al. (2017), Veras et al. (2018), Mendes et al. (2021), and Gomes et al. (2021). MP1 = Calymmian; MP1PP4 = Statherian-Calymmian; PP4 = Statherian; PP34 = Orosirian-Statherian. 
crystallization ages between $1785 \pm 2 \mathrm{Ma}$ (Pb-Pb evaporation) and $1777 \pm 4 \mathrm{Ma}$ (U-Pb SHRIMP) (Almeida et al. 2013). The São Jorge Facies is assigned to monzogranitic leucogneisses, with fine to medium granulation, and with manganese garnet (spessartite). These rocks have an alkaline chemical signature that differs from the other Cauaburi Complex lithotypes. However, the structural/metamorphic characteristics of the São Jorge Facies are similar to the Cauaburi Complex's facies (Carneiro et al. 2017).

In the western Cauaburi Complex, Rodrigues (2016) and Mendes et al. $(2020,2021)$ relate a low-angle to subvertical E-W-trending foliation as S1 (i.e. magmatic and solid-state foliations), affecting the Cauaburi Complex metagranitoids. However, in others sites, a NE-SW-trending foliation (S1) was related to the syn-tectonic intrusion of Cauaburi magmas (Carneiro et al. 2017; Veras et al. 2018). Besides, these authors describe the overprinting of a NW-SE-trending foliation (S2) and later shear zones (S3) that reactivated the previouslyestablished structural planes.

\subsubsection{Querari Complex}

At first, the basement rocks of the Alto Rio Negro Domain were considered as part of the Cumati Complex, which has been subdivided into the Querari and Tonu facies (Almeida 2006). After the reorganization of the basement rocks by Almeida et al. (2013), the Querari Facies turn into the Querari Complex and becomes the Alto Rio Negro Domain basement (Almeida 2013 - Figure 6), while the Tonu Facies was renamed to Cumati Facies (Cauaburi Complex), representing part of the basement of the Imeri Domain (Carneiro et al. 2017). According to Almeida et al. (2013), the Querari Complex rocks show calcalkaline chemistry with low- to medium-K, crystallization ages in the 1.74-1.70 Ga interval (Table 1), and model age of 1.82 $\mathrm{Ga}$ with $\varepsilon \mathrm{Nd}$ of +4.05 . The formation of these rocks is assigned to an island arc setting.

Gomes (2018) and Gomes et al. (2021) reviewed the rocks of the Querari Complex in the extreme northwest of the Amazonas state and identified two facies named Panã-Panã and Matapi (Figure 5). Both facies are silica-rich and with syenogranitic to monzogranitic composition. These rocks are orthogneisses and metagranites, with coarse granulation and often porphyritic texture, differing in mineralogical content and chemical signature. The rocks from the Panã-Panã Facies have titanite and epidote, and calc-alkaline metaluminous chemical signature. The Matapi Facies are two-mica metagranites with epidote, and have peraluminous chemistry with normative corundum greater than $1 \%$. The geochemistry of the Matapi Facies is comparable with eastward metagranites hosted by the Taiuaçu-Cauera Complex (Igarapé Tocandira Granite; Mendes et al. 2020). The crystallization ages obtained for the Querari basement protolith is $1740 \pm 2$ Ma (Almeida et al. 2013; Pb-Pb evaporation in zircon). Tassinari et al. (1996) also reported an age of $1703 \pm 7 \mathrm{Ma}$ in a meta-quartz diorite, probably related to Querari Complex (Almeida et al. 2013).

Concerning the structural framework of this orthoderived basement, Gomes et al. (2021) described a magmatic foliation (S0) parallel to a solid-state secondary foliation (S1), with subvertical NE-SW attitude, in addition to an overprinting foliation (S2) formed in the axial plane of folds that affected S1 and presents subvertical E-W attitude. Shear zones parallel to S1 form a mylonitic foliation (S3).

\subsection{Statherian anorogenic magmatism}

Firstly designated as Tiquié Granite (Pinheiro et al. 1976), the equigranular granites, with medium to coarse grains, locally porphyritic, that form a series of inselbergs in the central-eastern portion of the Alto Rio Negro region form the Tiquié, Marié-Mirim, and Marauiá suites (Almeida 2006). These units are attributed to the late- to post-tectonic magmatism of the Cauaburi Orogeny and have crystallization ages around 1.76-1.75 Ga (Almeida 2006; Table 1). The separation between these three units was due to location and chemistry differences.

According to Almeida (2006), the Tiquié Suite is located in the western Alto Rio Negro region and consists of subalkaline, metaluminous, A-type granites, formed by alkali feldspar, plagioclase, quartz, biotite, hornblende, titanite, allanite, fluorite, zircon, and opaque minerals. In the central-east portion, the Marauiá Suite forms inselbergs aligned according to NE-SW and NW-SE trends. These rocks are essentially formed by quartz, plagioclase, alkali feldspar, and biotite, with occasional hastingsite and accessory minerals like allanite, epidote, titanite, zircon, apatite, and opaque minerals. Chemically, they are subalkaline granites, ranging from metaluminous to peraluminous with occasional peralkaline terms (when with hastingsite), with high levels of silica and alkali, in addition to a high FeOt/ $\mathrm{MgO}$ ratio. The Marié-Mirim Suite is made up of intensely deformed equigranular granites, presenting cataclastic and mylonitic textures. They are composed of alkali feldspar, bluish quartz, plagioclase, and biotite as the main mineralogy. Allanite, opaque, epidote, zircon, apatite, fluorite, titanite, and riebeckite-arfvedsonite are the accessory phases. These rocks are chemically classified as peralkaline, compatible with "anorogenic granites generated in an attenuated crust environment" (Almeida 2006).

\subsection{Metasedimentary succession}

The Tunuí Group comprises the low-grade metasedimentary successions (greenschist metamorphic conditions) of the western Alto Rio Negro region (e.g. Tunuí, Caparro, Macaco, Serrinha, and Traíras ranges) that were grouped in Tunuí-Caparro Lithofacies, in addition to paragneisses and migmatites grouped in the Taiuaçu-Cauera Lithofacies (Almeida 2006). This author interprets that the Paleoproterozoic calc-alkaline rocks form the basement of these metasedimentary successions. Santos (2003) presents $\mathrm{U}-\mathrm{Pb}$ ages in detrital zircon grains of $1916 \pm 57,1782 \pm 8$, and $1720 \pm 11$ to a Serrinha Range's quartzite sample.

However, although these low-grade successions have traditionally been grouped under Tunuí Group nomenclature, the high-grade metamorphic rocks were previously related to basal complexes (Montalvão et al. 1975; Pinheiro et al. 1976; Melo and Villas Boas 1993). Veras et al. (2018) present geochronological data that confirm that the Taiuaçu-Cauera lithotypes are older than those of the Cauaburi Complex and, therefore, do not belong to the Tunuí Group but to the regional basement, as also confirmed by the geochronological data presented in Mendes et al. (2021). Furthermore, Veras et al. (2018) interpret that these Taiuaçu-Cauera rocks also include orthoderived protoliths. Mendes et al. (2020) formalized this geological unit as the Taiuaçu-Cauera Complex, which groups the high-grade metasedimentary rocks of the Alto Rio Negro region. 
According to Mendes et al. (2021), the Taiuaçu-Cauera Complex's partial melting during the Paleoproterozoic orogeny (Cauaburi magmatic arc) produced peraluminous granitic plutons in the Alto Rio Negro region, named Igarapé Tocandira Granite (Figure 5). These rocks are metamorphosed two-mica syenogranites that intruded the high-grade metasedimentary rocks of the Taiuaçu-Cauera Complex, with crystallization age $(1790 \pm 4.5 \mathrm{Ma}$; U-Pb in zircon) coeval with the metamorphic age of the host-rocks (1794 $\pm 15 \mathrm{Ma}$; U-Pb in zircon) (Table 1).

The eastern low-grade metasedimentary successions (Imeri Domain - IMD) are attributed to the Aracá, Daraá, and Neblina formations, coeval to the Tunuí Group (Almeida 2006). The Aracá Formation is described as a low-grade, metasedimentary succession, related to a fluvial depositional environment (Giovannini and Larizzatti 1994). U-Pb dating in detrital zircon grains reveals a younger peak in $1879 \pm 15$ $\mathrm{Ma}$, and an Ar-Ar analysis in muscovite provided an age of $1337 \pm 4$, interpreted as a metamorphic age (Santos 2003). According to Luzardo (2000), the Daraá Formation represents a metasedimentary succession, and Melo et al. (1993) report the presence of interspersed metatuff. Melo and Villas Boas (1993) relate a succession of metarudites and metapsamites in a description in the Padre Range, also grouped in the Serra da Neblina Formation.

There are still many controversies regarding the age of these metasedimentary successions, given the absence of descriptions of geologic relations (e.g. crosscutting by igneous units or intercalation of volcanic layers) or more comprehensive geochronological data. The detrital grains age records are limited to a few grains, making it difficult to assign a maximum age. As for metamorphism, only the Aracá Range has a metamorphic age published (1337 $\pm 4 \mathrm{Ma}$; Santos 2003), but it would be pretentious to expand that interpretation to the other Alto Rio Negro (meta)sedimentary successions.

\subsection{Calymmian magmatism}

Almeida et al. (2013) also compiled data of varied Calymmian granitoids (attributed to the Içana Orogeny) that intruded the Paleoproterozoic basement. Cropping out around the São Gabriel da Cachoeira town and in the Lower Uaupés River, I-type granitic bodies (hornblende-biotite monzogranites; Souza 2009) with crystallization ages of ca. $1.52 \mathrm{Ga}$ (U-Pb in zircon; Santos 2003) are interpreted as precollisional. Along the Içana River margins, muscovite-biotite granites are interpreted as S-type syn- to late-collisional granites, grouped in the Rio Içana Suite. These rocks have a crystallization age (Pb-Pb evaporation) of $1521 \pm 31 \mathrm{Ma}$ and $1521 \pm 32$ Ma (Table 1), according to Tassinari et al. (1996) and Almeida et al. (1997), respectively. The Inhamoin Suite granitoids present a crystallization age ( $\mathrm{Pb}-\mathrm{Pb}$ evaporation) of $1483 \pm 2 \mathrm{Ma}$ (Almeida et al. 2013) and chemical affinity with A-type rocks, aluminous and highly oxidized (Dall'Agnol 1992; Dall'Agnol and Macambira 1992), produced in the postcollisional phase.

\subsection{Seis Lagos carbonatite}

The presence of three circular radiometric anomalies (Pinheiro et al. 1976), ca. $60 \mathrm{~km}$ northward of São Gabriel da Cachoeira, led to the discovery of intrusive alkaline bodies that host the largest deposit of niobium in the world (Viegas Filho and Bonow 1976; Justo and Souza 1986), with mineralization in the REE- and Nb-rich laterite. Issler and Silva (1980) recognized that these intrusive bodies are carbonatites, assigning the Seis Lagos Carbonatitic Complex denomination. The host rocks, biotite-hornblende orthogneisses, present crystallization ages of $1810 \pm 10 \mathrm{Ma}$ (Santos et al. 2000) and $1828 \pm 9$ Ma (Rossoni et al. 2017; Table 1). The carbonatite emplacement was controlled by a $400 \mathrm{~km}$ length lineament that follows an E-W trend (Rossoni et al. 2016) and developed in the Ectasian Period (1328 $\pm 58 \mathrm{Ma}$; Rossoni et al. 2017). Rossoni et al. (2017) interpret that the generation of this magmatism may be related to the final stage of Içana Orogeny (Almeida et al. 2013) or due to the crustal reworking of the K'Mudku Intracontinental Orogen (Santos et al. 2008).

\subsection{Cenozoic covers}

A wide and flattened deposition site of sandy sediments was described by Paiva (1929), extending from the Içana to the Uaupés river. Melo and Villas Boas (1993) considered this sedimentary cover an extension of the Içá Formation in the region. In Santos and Nelson (1995) conception, this unit is a distinct basin named Aiari Basin.

Latrubesse and Franzinelli (1998) studied the river deposits on the banks of the major local rivers. The authors divide the Quaternary fluvial sedimentation into three units: sediments from upper terraces, sediments from lower terraces, and recent floodplains. The upper terrace sediments are sandy and rich in organic matter and iron oxides, with radiocarbon (14C) ages of more than 40000 to $27220 \pm 200$ years. The sediments of the lower terraces are aged between 13500 and 4050 years (14C). Franzinelli and Potter (1983) describe the recent floodplain as sandy sediments with more than $98 \%$ of quartz grains deposited along riverbeds and their margins.

\section{Tectonic models}

Almeida (2006) subdivided the Rio Negro Province into two tectonostratigraphic domains, Alto Rio Negro (westward) and Imeri (eastward) (Figure 6). The Cumati Complex is related to the Alto Rio Negro Domain basement rocks, subdivided into Tonu Facies (eastward) and Querari Facies (westward). In the Imeri Domain, the Cauaburi Complex represents the geological basement subdivided in the Tarsira and Santa Izabel of the Rio Negro facies.

Based on field, geochemical, and geochronological data Almeida et al. (2013) redefined the boundary of the Imeri Domain, subdividing the Alto Rio Negro Domain into the Içana Domain and the Uaupés Domain (Figure 7). In this new configuration, the Alto Rio Negro Domain basement was divided into two complexes, the Querari Complex (former Querari Facies) that represents the Uaupés Domain basement, and the Cumati Complex (former Tonu Facies) that is part of the Imeri Domain basement, besides extending its limit to the west. In the Içana Domain, located between the Uaupés and Imeri domains, the remnants of the Tunuí Group's metavolcanosedimentary succession represent the basement and are associated with the Calymmian S-type granites of the Içana Suite.

According to Almeida et al. (2013), the structural framework of the Rio Negro Province results from distinct subduction tectonics and the collision of these magmatic 
TABLE 1. Geochronological data of the Brazilian portion of the Rio Negro Province.

\begin{tabular}{|c|c|c|c|c|c|c|c|}
\hline Lithostratigraphic unit & Sample & Latitude & Longitude & Lithotype & Age (Ma) & Method & Reference \\
\hline Cauaburi Complex & SG-01-AM/04 & $0^{\circ} 17^{\prime} 13.7 " \mathrm{~N}$ & $66^{\circ} 41^{\prime} 04.7^{\prime \prime} \mathrm{W}$ & Fragmented laterite crust & $1874 \pm 56$ & II in $\mathrm{Zr}$ & Rossoni et al. (2017) \\
\hline Cauaburi Complex & SG-02-AM/22 & $0^{\circ} 17^{\prime} 16.8 \prime \mathrm{N}$ & $66^{\circ} 41^{\prime} 28.8^{\prime \prime} \mathrm{W}$ & Feldspar vein in gneiss & $1839 \pm 29$ & $\mathrm{II}$ in $\mathrm{Zr}$ & Rossoni et al. (2017) \\
\hline Cauaburi Complex & SG-02-AM/35 & $0^{\circ} 17^{\prime} 16.8 ” \mathrm{~N}$ & $66^{\circ} 41^{\prime} 28.8^{\prime \prime} \mathrm{W}$ & Orthogneiss & $1828 \pm 09$ & II in $\mathrm{Zr}$ & Rossoni et al. (2017) \\
\hline Cauaburi Complex & SG-01-AM/01 & $0^{\circ} 17^{\prime} 13.7 " \mathrm{~N}$ & $66^{\circ} 41^{\prime} 04.7^{\prime \prime} \mathrm{W}$ & Pisolitic laterite crust & $1828 \pm 12$ & II in $\mathrm{Zr}$ & Rossoni et al. (2017) \\
\hline Cauaburi Complex & $R L-19 A$ & $0^{\circ} 55^{\prime} 24.3^{\prime \prime} \mathrm{N}$ & $67^{\circ} 29^{\prime} 13.9^{\prime \prime} \mathrm{W}$ & Bt augen gneiss & $* 1530 \pm 7$ & $\mathrm{I}$ in $\mathrm{Zr}$ & Veras et al. (2019) \\
\hline \multirow{2}{*}{ Cauaburi Complex } & \multirow{2}{*}{ MA21A } & \multirow{2}{*}{$1^{\circ} 45^{\prime} 41.9^{\prime \prime} \mathrm{N}$} & \multirow{2}{*}{$68^{\circ} 06^{\prime} 52.4^{\prime \prime} \mathrm{W}$} & \multirow{2}{*}{ Bt metagranite } & $1813 \pm 19$ & \multirow{2}{*}{$I$ in $Z r$} & \multirow{2}{*}{ Veras et al. (2018) } \\
\hline & & & & & $\# 1911 \pm 15$ & & \\
\hline Cauaburi Complex & MS-63 & $0^{\circ} 04^{\prime} 10.3^{\prime \prime} \mathrm{N}$ & $66^{\circ} 3^{\prime} 26.6^{\prime \prime} \mathrm{W}$ & Monzogranite & $1810 \pm 9$ & III in $\mathrm{Zr}$ & Santos et al. (2000) \\
\hline Cauaburi Complex & SS-31 & $1^{\circ} 36^{\prime} 32.0^{\prime \prime} \mathrm{S}$ & $60^{\circ} 35^{\prime} 27.0^{\prime \prime} \mathrm{W}$ & Orthogneiss & $1807 \pm 6$ & III in $\mathrm{Zr}$ & Almeida et al. (2013) \\
\hline Cauaburi Complex & MS-327 & - & - & Monzogranite & $1806 \pm 6$ & III in $\mathrm{Zr}$ & Santos et al. (2000) \\
\hline \multirow{2}{*}{ Taiuaçu-Caueira Complex } & \multirow{2}{*}{ MA29 } & \multirow{2}{*}{$1^{\circ} 24^{\prime} 60^{\prime \prime} \mathrm{N}$} & \multirow{2}{*}{$68^{\circ} 00^{\prime} 50.1^{\prime \prime} \mathrm{W}$} & \multirow{2}{*}{ Heterogeneous diatexite } & *1798 \pm 11 & \multirow{2}{*}{$\mathrm{I}$ in $\mathrm{Zr}$} & \multirow{2}{*}{ Veras et al. (2018) } \\
\hline & & & & & $\# 1842 \pm 9$ & & \\
\hline \multirow{2}{*}{ Cauaburi Complex } & \multirow{2}{*}{ J0-69 } & \multirow{2}{*}{$0^{\circ} 37^{\prime} 25.0 " S$} & \multirow{2}{*}{$64^{\circ} 47^{\prime} 49.5^{\prime \prime} \mathrm{W}$} & \multirow{2}{*}{ Foliated granite } & $1798 \pm 3$ & \multirow{2}{*}{ III in $\mathrm{Zr}$} & Sontoge $(2000$ \\
\hline & & & & & *1468 \pm 8 & & odilos $(2000)$ \\
\hline Cauaburi Complex & JO-75 & $0^{\circ} 53^{\prime} 04.1^{\prime \prime} \mathrm{N}$ & $63^{\circ} 02^{\prime} 56.6^{\prime \prime} \mathrm{W}$ & Orthogneiss & $1796 \pm 6$ & III in Zr & Santos (2003) \\
\hline Cauaburi Complex & MA-49 & $0^{\circ} 48^{\prime} 41.0^{\prime \prime} \mathrm{N}$ & $67^{\circ} 32^{\prime} 43.0^{\prime \prime} \mathrm{W}$ & Orthogneiss & $1795 \pm 2$ & $\mathrm{IV}$ in $\mathrm{Zr}$ & Almeida et al. (2013) \\
\hline Cauaburi Complex & CG-08 & $0^{\circ} 24$ '40.0"S & $65^{\circ} 09^{\prime} 14.8^{\prime \prime} \mathrm{W}$ & Tonalite & $1795 \pm 6$ & III in $\mathrm{Zr}$ & Santos et al. (2006) \\
\hline Taiuaçu-Caueira Complex & TM-R-82 & $1^{\circ} 43^{\prime} 35.4^{\prime \prime} \mathrm{N}$ & $68^{\circ} 22^{\prime} 50.2^{\prime \prime} \mathrm{W}$ & Migmatite (paleossome) & *1794 $\pm 15,1782.2 \pm 5.6$ & III in Zr & Mendes et al. (2021) \\
\hline & & & & & $\# 1858 \pm 17,1819.4 \pm 4.9$ & & \\
\hline Cauaburi Complex & CS-38 & $0^{\circ} 25^{\prime} 18.0 " \mathrm{~S}$ & $64^{\circ} 46^{\prime} 29.0^{\prime \prime} \mathrm{W}$ & Mylonitic monzogranite & $* 1490 \pm 3$ & III in Ttn & Santos et al. (2006) \\
\hline Cauaburi Complex & CG-08 & $0^{\circ} 24^{\prime} 40.0^{\prime \prime} \mathrm{S}$ & $65^{\circ} 09^{\prime} 14.8^{\prime \prime} \mathrm{W}$ & Tonalite gneiss & $1789 \pm 6$ & $\mathrm{I}$ in $\mathrm{Zr}$ & Almeida et al. (2000) \\
\hline Таниаси-Саиеira Complex & MA44 & $1^{\circ} 22^{\prime} 585^{\prime \prime} \mathrm{N}$ & & Heterngene & *1788 \pm 11 & & Ver \\
\hline raıaçu-caueira complex & IVIA44 & $12258.5 \mathrm{~N}$ & $680409.1 \mathrm{~W}$ & Heterogeneous diatexite & $\# 1821 \pm 14$ & I In $\angle r$ & Veras et al. (2018) \\
\hline Jaarané Reilau Suite & CS-102 & $0^{\circ} 56^{\prime} 324 " \mathrm{~N}$ & $63^{\circ} 40^{\prime} 124 " \mathrm{~W}$ & Granite & $1787 \pm 13$ & III in $\mathrm{Zr}$ & Santos et al (2006) \\
\hline Igarape ReIlau Suite & $\operatorname{cs-102}$ & $0.5632 .4 \times \mathrm{N}$ & $634012.4 \mathrm{~W}$ & Granite & $* 1423 \pm 14$ & III in Ms & \\
\hline Cauaburi Complex & MA-31 & $1^{\circ} 20^{\prime} 22.0^{\prime \prime} \mathrm{N}$ & $67^{\circ} 14^{\prime} 16.0^{\prime \prime} \mathrm{W}$ & Orthogneiss & $1785 \pm 2$ & IV in $\mathrm{Zr}$ & Almeida et al. (2013) \\
\hline Cauaburi Complex & $\mathrm{HB}-667$ & $1^{\circ} 04^{\prime} 14.0 " \mathrm{~N}$ & $69^{\circ} 21^{\prime} 37.6^{\prime \prime} \mathrm{W}$ & Monzogranite & $1778 \pm 5.9$ & III in $\mathrm{Zr}$ & Cordani et al. (2016) \\
\hline Cauaburi Complex & MA-39 & $1^{\circ} 52^{\prime} 32.0^{\prime \prime} \mathrm{N}$ & $67^{\circ} 32^{\prime} 35.0^{\prime \prime} \mathrm{W}$ & Orthogneiss & $1777 \pm 4$ & III in $\mathrm{Zr}$ & Almeida et al. (2013) \\
\hline Jarrané Tosandira aranito & 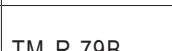 & $1{ }^{\circ} 3,178 " \mathrm{~N}$ & $68021{ }^{\prime} 36$ " W & Mc_Bt metacyenearanite & $1770.8 \pm 8.4$ & 11 in $7 r$ & Mendes et al (2021) \\
\hline Igarape Iocandıra granite & $|I M|-R-19 B$ & $14317.8 \mathrm{~N}$ & $682136.4 \mathrm{~W}$ & Ms-Bt metasyenogranite & $\# 1790.5 \pm 4.5$ & III In $\angle \mathrm{r}$ & Mendes et al. (2021) \\
\hline Cauaburi Complex & $\mathrm{GH}-\mathrm{R}-06$ & $1^{\circ} 43^{\prime} 505^{\prime \prime} \mathrm{N}$ & $68^{\circ} 88^{\prime} 319^{\prime \prime W}$ & Bt metamonzogranite & $1763 \pm 7$ & & Mendes et a s \\
\hline cauaburt complex & GH-R-Ub & $1.4350 .5 \mathrm{~N}$ & $08031.9 \mathrm{VW}$ & Bt metamonzogranite & $a 1783.4 \pm 3.2,1805 \pm 15$ & III In $\angle r$ & Mendes et al. $(\angle 0 \angle 1)$ \\
\hline & $T M-R-26$ & $1^{\circ} 29^{\prime} 388 " \mathrm{~N}$ & $68^{\circ} 11^{\prime} 74 " W$ & Hbl metagranodiorite & $1759.0 \pm 5.3$ & 11 in $7 r$ & Mendes et al (2021) \\
\hline Cauaburı complex & $\mathrm{IM}-\mathrm{R}-26$ & $12938.8 \mathrm{~N}$ & $68117.4 \mathrm{~W}$ & HbI metagranodıorite & a $1776.1 \pm 7.9$ & III In $\angle r$ & Mendes et al. (2021) \\
\hline Marié_Mirim Suite & FP_189 & חי29'0 $5 " \mathrm{~N}$ & $66^{\circ} 13.253 " \mathrm{~W}$ & Syenogranite & $1756 \pm 12$ & IV in $7 r$ & Almeida $(2006)$ \\
\hline Marıe-IMırım suite & EP-189 & $0 \angle 20 \angle .5 \mathrm{~N}$ & $00 \quad 10<0.0 \mathrm{~V}$ & syenogramie & $\# 1805 \pm 8$ & IV III LI & Amाtera $(2000)$ \\
\hline Cauaburi Complex & $\mathrm{GH}_{-} \mathrm{R}-16$ & $1{ }^{\circ} 50$ ' $4 " \mathrm{~N}$ & $68016 ' 448 " \mathrm{~W}$ & Hhl metagranodiorite & $1754 \pm 7$ & $1 \mu$ in $7 r$ & Mendec et al (2021) \\
\hline cauanun complex & $G \Pi-R-10$ & $15002.4 \mathrm{~N}$ & $001044.0 \mathrm{VV}$ & not metagramoutome & $a 1776.3 \pm 3.9,1801.7 \pm 6.9$ & 111 III Z1 & Iveriues el al. $(20<1)$ \\
\hline Tiquié Suito & $A F-338$ & $0 \circ 04 \cdot 323 " \mathrm{~N}$ & & Mc monzogranito & $1749 \pm 5$ & & \\
\hline Iıquie suite & AF-338 & $00432.31 \mathrm{~N}$ & $694833.4 \mathrm{~W}$ & Ms monzogranite & $\# 2034 \pm 2$ & IV In $\angle \mathrm{r}$ & Almeida (2006) \\
\hline & & $0 \circ 31,553 " \mathrm{C}$ & 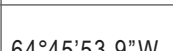 & & $1746 \pm 6$ & IV in $7 r$ & Almeida $(2006)$ \\
\hline Marauiá Suite & PV-38 & $00^{\circ} 3155.3 " \mathrm{~S}$ & $64^{\circ} 45^{\circ} 53.9^{\prime \prime} \mathrm{W}$ & Monzogranite & $\# 1784 \pm 7$ & IV in $\angle r$ & Almeida (2006) \\
\hline Tiquié Suite & $A F-338$ & $0^{\circ} 04^{\prime} 32.3^{\prime \prime} \mathrm{N}$ & $69^{\circ} 48^{\prime} 33.4^{\prime \prime} \mathrm{W}$ & Ms Monzogranite & $1746 \pm 5$ & III in Zr & Almeida (2006) \\
\hline Querari Complex & JH-33A & $1^{\circ} 04^{\prime} 32.0^{\prime \prime} \mathrm{N}$ & $69^{\circ} 28^{\prime} 32.0^{\prime \prime} \mathrm{W}$ & $\mathrm{Hbl}$ gneiss & $1740 \pm 2$ & IV in $\mathrm{Zr}$ & Almeida et al. (2013) \\
\hline Querari Complex & UA-39 & $1^{\circ} 04^{\prime} 06.2^{\prime \prime} \mathrm{N}$ & $69^{\circ} 30^{\prime} 34.1^{\prime \prime} \mathrm{W}$ & Quartz-diorite & $1703 \pm 7$ & III in $\mathrm{Zr}$ & $\begin{array}{l}\text { Tassinari et al. } \\
(1996)\end{array}$ \\
\hline Aracá Eormation & $c g-30$ & 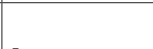 & - & Sil-Ms schist & $\# 1879 \pm 15$ & III in $\mathrm{Zr}$ & Santos et al (2006) \\
\hline Araca romation & CG-30 & - & - & SII-IVIS SCnISt & *1337 \pm 11 & $\mathrm{VI}$ in Ms & santos el al. (2000) \\
\hline Tunuí Group & AF-327 & $0^{\circ} 26^{\prime} 22.3^{\prime \prime} \mathrm{N}$ & $69^{\circ} 22^{\prime} 18.4^{\prime \prime} \mathrm{W}$ & Ms quartzite & $\# 1782 \pm 8,1720 \pm 11$ & $\mathrm{III}$ in $\mathrm{Zr}$ & Santos (2003) \\
\hline Rin Icana Suite & $C_{-}-102$ & $0 \circ 56,324 " \mathrm{~N}$ & $63^{\circ} 40^{\prime} 124^{\prime \prime} \mathrm{W}$ & Ms leurouranite & $1537 \pm 4$ & 111 in $7 r$ & Almeida $(2006)$ \\
\hline RTo içalld sulte & US-1UL & $05052.4 \mathrm{~N}$ & $004012.4 \mathrm{VV}$ & IVIs reucogramie & $\# 1787 \pm 13$ & IIII III LI & Almerdad (८000) \\
\hline
\end{tabular}


TABLE 1. Geochronological data of the Brazilian portion of the Rio Negro Province. (continued)

\begin{tabular}{|c|c|c|c|c|c|c|c|}
\hline Lithostratigraphic unit & Sample & Latitude & Longitude & Lithotype & Age (Ma) & Method & Reference \\
\hline \multirow[b]{2}{*}{ Rio Içana Suite } & \multirow[b]{2}{*}{ AF-151 } & \multirow[b]{2}{*}{$1^{\circ} 40^{\prime} 43.9^{\prime \prime} \mathrm{N}$} & \multirow[b]{2}{*}{$68^{\circ} 12^{\prime} 51.5^{\prime \prime} \mathrm{W}$} & \multirow[b]{2}{*}{ Ms monzogranite } & $1536 \pm 4$ & \multirow[b]{2}{*}{ IV in Zr } & \multirow[b]{2}{*}{ Almeida (2006) } \\
\hline & & & & & $\begin{array}{l}\# 1889 \pm 3,1805 \pm 10 \\
1745 \pm 13\end{array}$ & & \\
\hline \multirow{2}{*}{ Rio Içana Suite } & \multirow{2}{*}{ AM-44 } & \multirow{2}{*}{-} & \multirow{2}{*}{-} & \multirow{2}{*}{ Leucogranite } & $1523 \pm 7$ & \multirow{2}{*}{ III in $\mathrm{Zr}$} & \multirow{2}{*}{ Santos (2003) } \\
\hline & & & & & $\# 1701 \pm 15$ & & \\
\hline Rio Içana Suite & JH-18 & $0^{\circ} 52^{\prime} 29.6 " \mathrm{~N}$ & $69^{\circ} 08^{\prime} 11.3^{\prime \prime} \mathrm{W}$ & Ms-Bt granite & $1521 \pm 32$ & IV in $\mathrm{Zr}$ & Almeida et al. (1997) \\
\hline Uaupés Suite & PA-22 & $0^{\circ} 35^{\prime} 59.9^{\prime \prime} \mathrm{N}$ & $69^{\circ} 36^{\prime} 45.4^{\prime \prime} \mathrm{W}$ & Bt granite & $1521 \pm 13$ & $V$ in $Z r$ & $\begin{array}{l}\text { Tassinari et al. } \\
(1996)\end{array}$ \\
\hline Uaupés Suite & AF-01 & $0^{\circ} 25^{\prime} 28.5^{\prime \prime} \mathrm{S}$ & $65^{\circ} 08^{\prime} 13.4^{\prime \prime} \mathrm{W}$ & Granite with Ttn & $1518 \pm 25$ & $\mathrm{~V}$ in $\mathrm{Zr}$ & Santos et al. (2000) \\
\hline Rio Inhamoin Suite & RL-05 & - & - & Porphyrytic granite & $1483 \pm 2$ & IV in $\mathrm{Zr}$ & Almeida et al. (2013) \\
\hline \multirow{2}{*}{ Seis Lagos carbonatite } & \multirow{2}{*}{ SG-04-AM/73 } & \multirow{2}{*}{$0^{\circ} 16^{\prime} 54.2^{\prime \prime} \mathrm{N}$} & \multirow{2}{*}{$66^{\circ} 40^{\prime} 39.5^{\prime \prime} \mathrm{W}$} & \multirow{2}{*}{ Siderite carbonatite } & $1328 \pm 58$ & \multirow{2}{*}{ II in $\mathrm{Zr}$} & \multirow{2}{*}{ Rossoni et al. (2017) } \\
\hline & & & & & $\# 1812 \pm 27$ & & \\
\hline Seis Lagos carbonatite & SG-04-AM/70 & $0^{\circ} 16^{\prime} 54.2 ” \mathrm{~N}$ & $66^{\circ} 40^{\prime} 39.5^{\prime \prime} \mathrm{W}$ & Siderite carbonatite & $\# 1826 \pm 05$ & II in $\mathrm{Zr}$ & Rossoni et al. (2017) \\
\hline Seis Lagos carbonatite & SG-02-AM/53 & $0^{\circ} 17^{\prime} 16.8 ” \mathrm{~N}$ & $66^{\circ} 41^{\prime} 28.8^{\prime \prime} \mathrm{W}$ & Siderite carbonatite & $\# 1819 \pm 10$ & II in $\mathrm{Zr}$ & Rossoni et al. (2017) \\
\hline
\end{tabular}

In addition to the crystallization ages, the symbology next to the ages indicates: * = metamorphism, \# = heritage (xenocrysts), and $\alpha=$ previous magmatic pulses (antecrysts). Methods: I = U-Pb MC-ICP-MS; II = U-Pb MC-ICP-MS; III = U-Pb SHRIMP; IV = Pb-Pb evaporation; V = U-Pb ID-TIMS; and $\mathrm{VI}=\mathrm{Ar}-\mathrm{Ar}$. Mineral abbreviations: $\mathrm{Bt}=$ biotite, $\mathrm{Ms}=$ muscovite, $\mathrm{Hbl}=$ hornblende, $\mathrm{Ttn}=$ titanite, and $\mathrm{Zr}=\mathrm{zircon}$.

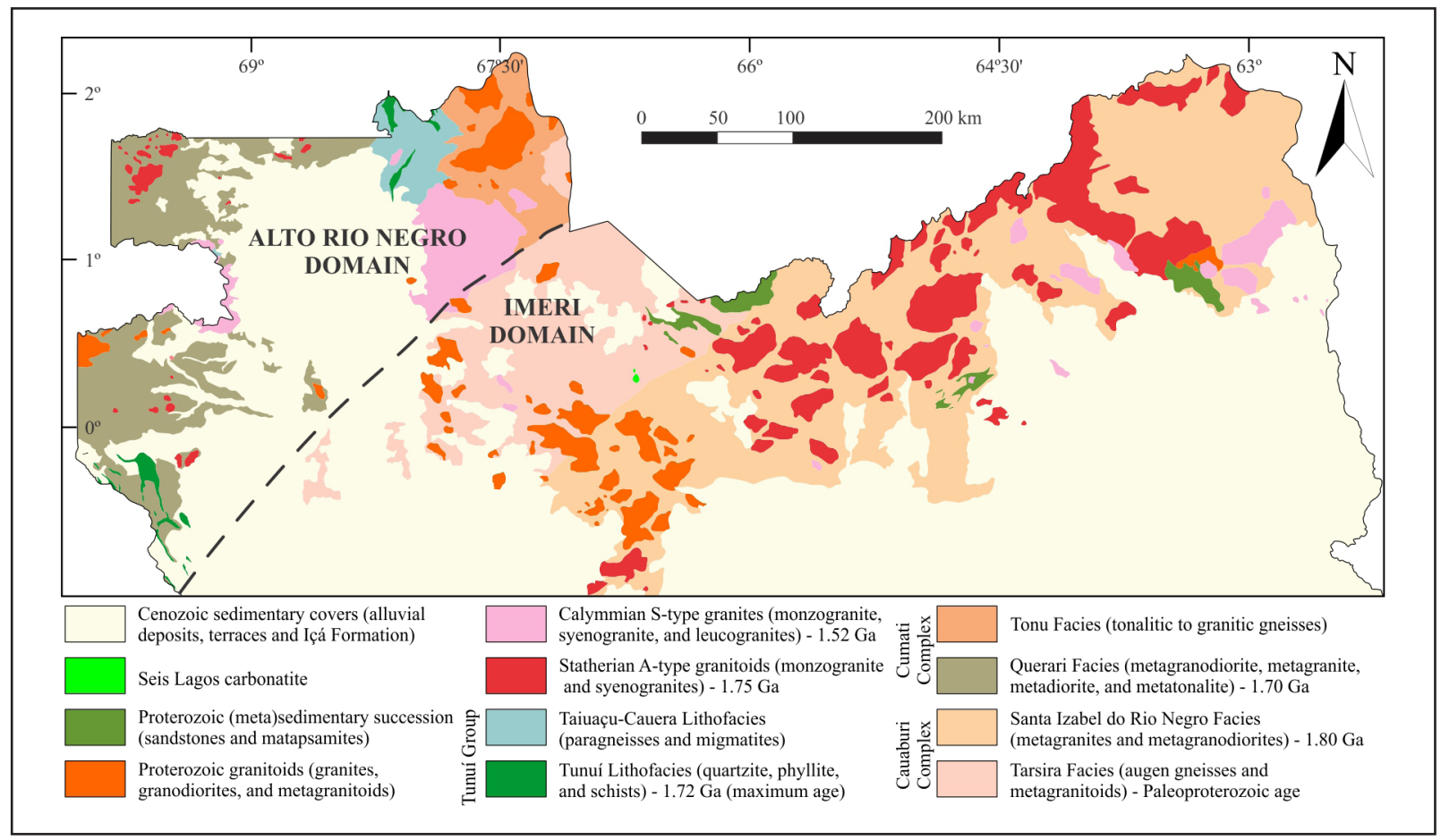

FIGURE 6. Geotectonic map of the Rio Negro Province in the Amazonas state, Brazil. Modified from Almeida (2006).

arcs with subsequent intracontinental rework. The tectonic events discriminated are: (i) the Cauaburi Orogeny occurs in the 1.81 to $1.78 \mathrm{Ga}$ interval, with the generation of the calcalkaline rocks of the Cauaburi Complex, in a continental arc environment, with a subducted plate dipping to the northeast under the Tapajós-Parima Province (Santos et al. 2002) and with the Neblina, Daraá and Aracá formations representing this arc-related basins; (ii) the Querari Orogeny, between 1.75-1.70 Ga, generates the Querari Complex in a juvenile magmatic arc system, and is associated with the deposition of protoliths from the Tunuí Group's metavolcanosedimentary succession; and (iii) the Içana Orogeny, in the range of 1.51 to $1.48 \mathrm{Ga}$, which results of the amalgamation of the Cauaburi and Querari arcs, generating granites from predominantly crustal sources of the Uaupés, Inhamoin, and Rio Içana suites, as well as deformation and metamorphism of the paraderived successions that resulted in the generation of the S-type granites of the Rio Içana Suite; and (iv) a later crustal reworking (1.38-1.20 Ga; K'Mudku Event) of intracratonic nature occurs, presenting similar age to the Sunsás Orogeny (Santos et al. 2008).

The most recent works (Carneiro et al. 2017; Veras et al. 2018) report three tectono-metamorphic events that affect the Cauaburi Complex rocks: D1 result in the development of high-temperature NE-SW-trending foliation, being responsible for the generation and syn-tectonic intrusion of Cauaburi magmas; D2 was also a high-temperature event (amphibolite to granulite facies) with development of NW-SE-trending 


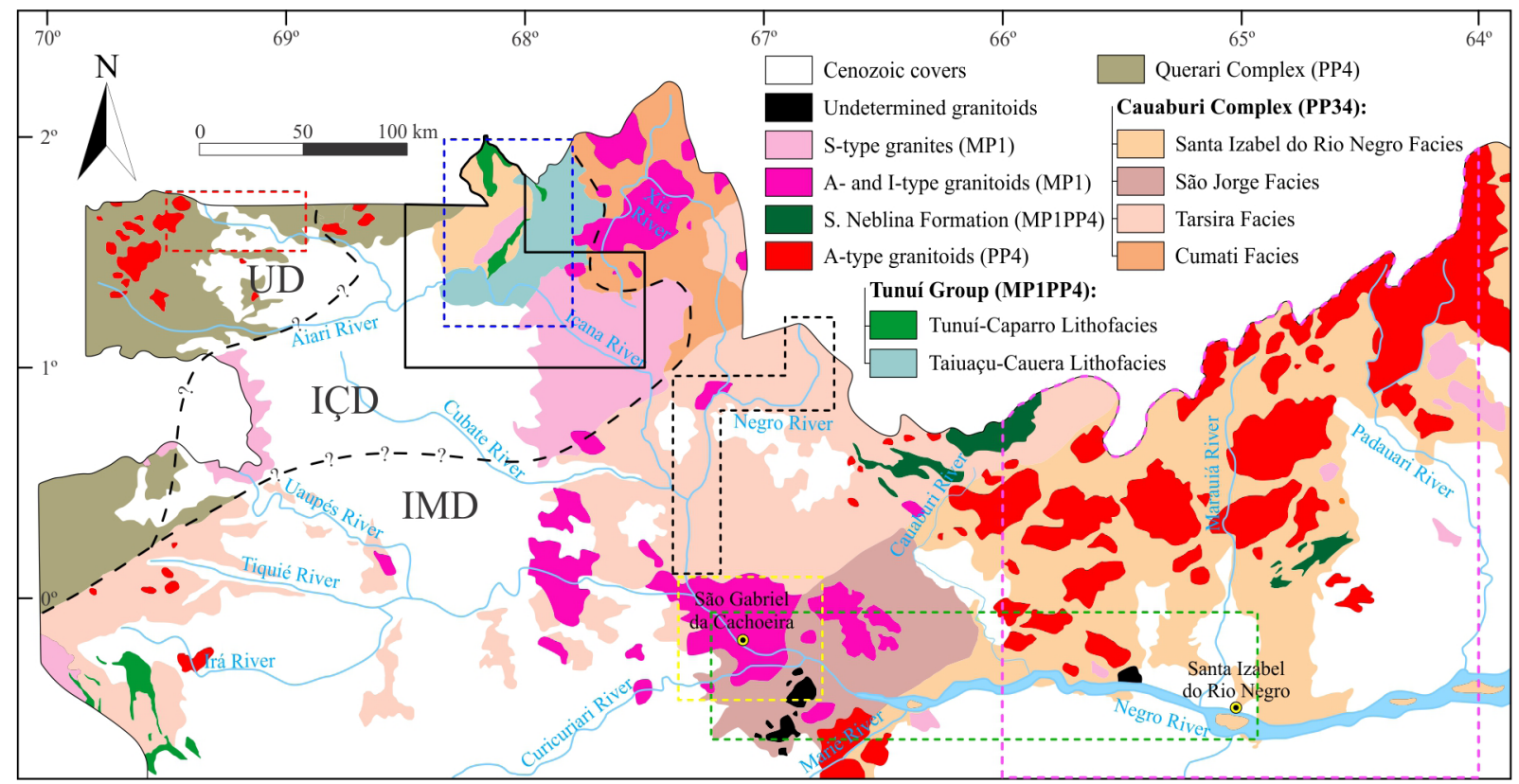

FIGURE 7. Geotectonic map of the Rio Negro Province in Brazil, highlighting the recent study areas. Modified from Almeida et al. (2013) and further improvements from Carneiro et al. (2017). Areas of works published in the last 20 years given by polygons with dotted lines of color: yellow (Souza 2009), blue (Veras 2012; Veras et al. 2018), green (Carneiro 2016; Carneiro et al. 2017), black (Rodrigues 2016), red (Gomes 2018; Gomes et al. 2021). The continuous black line corresponds to a geological mapping area on a 1:250,000 scale (Mendes et al. 2020), while the pink dotted line corresponds to a 1:500,000 scale mapping (Almeida et al. 2000).

foliation and emplacement of the Calymmian granites (Rio Içana, Uaupés, and Inhamoin suites); and the low-temperature D3 event (greenschist facies) with the reworking of the oldest NE-SW foliation associated with the K'Mudku Event.

Mendes et al. (2021) discuss the spatiotemporal variations of the cordilleran magmatism of the Cauaburi Belt. The eastern belt geochronological record varies from 1.81 to $1.78 \mathrm{Ga}$, while the western side presents the earliest crystallization ages at ca. $1.76 \mathrm{Ga}$ and zircon crystals population dating between 1805 and $1773 \mathrm{Ma}$ (Figure 8). These authors interpret that the western Cauaburi Belt is composed of long-lived composite plutons (tonalitic to syenogranitic composition - Cauaburi Complex) hosted by high-grade paraderived rocks (TaiuaçuCauera Complex; Figure 5), both affected by a syn-tectonic ENE-WSW-trending steeply-dipping foliation. Gomes et al. (2021) question the Querari Orogeny existence by identifying a similar tectonometamorphic evolution in the Querari and Cauaburi complexes (Carneiro et al. 2017; Veras et al. 2018) and suggest the existence of a long-lived continental magmatic arc (1.80-1.74 $\mathrm{Ga})$ responsible for the generation of both complexes.

On the other hand, Cordani et al. (2016) present a different tectonic proposal and relate the Rio Negro Province's evolution to two orogenic events. The first event (1.80 and $1.74 \mathrm{Ga}$; Atapabo Belt) generates the Rio Negro Province basement in a series of magmatic arcs piled up by soft-collision episodes and successive stacking from SW to NE under the cratonic area of the Ventuari-Tapajós continent. During the Calymmian, the Vaupés Belt (1.58-1.50 Ga) generates syn-tectonic granites in a subduction-related setting, but with subduction under the Statherian-aged cratonized area. Finally, intraplate heating (Nikerie-K'Mudku Event) between 1.30 and $1.20 \mathrm{Ga}$ affected the entire region.

\section{Conclusions and recommendations}

As highlighted by this literature review article, the works dedicated to the geological recognition carried out in the late 20th century, resulting from the RADAMBRASIL Project, revealed the main features and geological issues of the Alto Rio Negro region. More recently, contributions from academia and the Geological Survey of Brazil have elucidated some of these issues (e.g. structural geology, petrology, isotopic geology, and tectonics). However, as it is an extensive territory in which the outcrops described are far-between at a kilometric scale, most geological traits have not yet been revealed.

Most recent works focused on the geological basement, addressing field, chemical, and isotopic data. However, doubts remain about the existence of two magmatic arcs (i.e. Cauaburi - 1.81-1.76 Ga; and Querari - 1.74-1.70 Ga) or a long-lived continental magmatic arc $(1.83-1.70 \mathrm{Ga})$. Furthermore, the paleobasins (i.e. Taiuaçu-Cauera, Tunuí, and Neblina) also demand more in-depth characterization and comprehensive geochronological data to understand their tectonic roles. Finally, the intrusive bodies that intrude this basement were the least studied rocks in the region, needing more attention in further scientific works.

After about 170 years of research in the region, the biggest obstacle to the Alto Rio Negro region's geological knowledge advancement remains the lack of basic geological mapping and high-resolution aerogeophysical survey (at least 500 meters spacing). An example is the Aiari River basin (Figure 5) that has only brief reports in Wallace (1853) and Paiva (1929). Besides, the only 1:250.000 scale map (major scale for the region) was published recently, covering an area of only three 1:100.000 sheets (Mendes et al. 2020). The lack of such primary data leads to few researchers focusing on the region to glimpse 


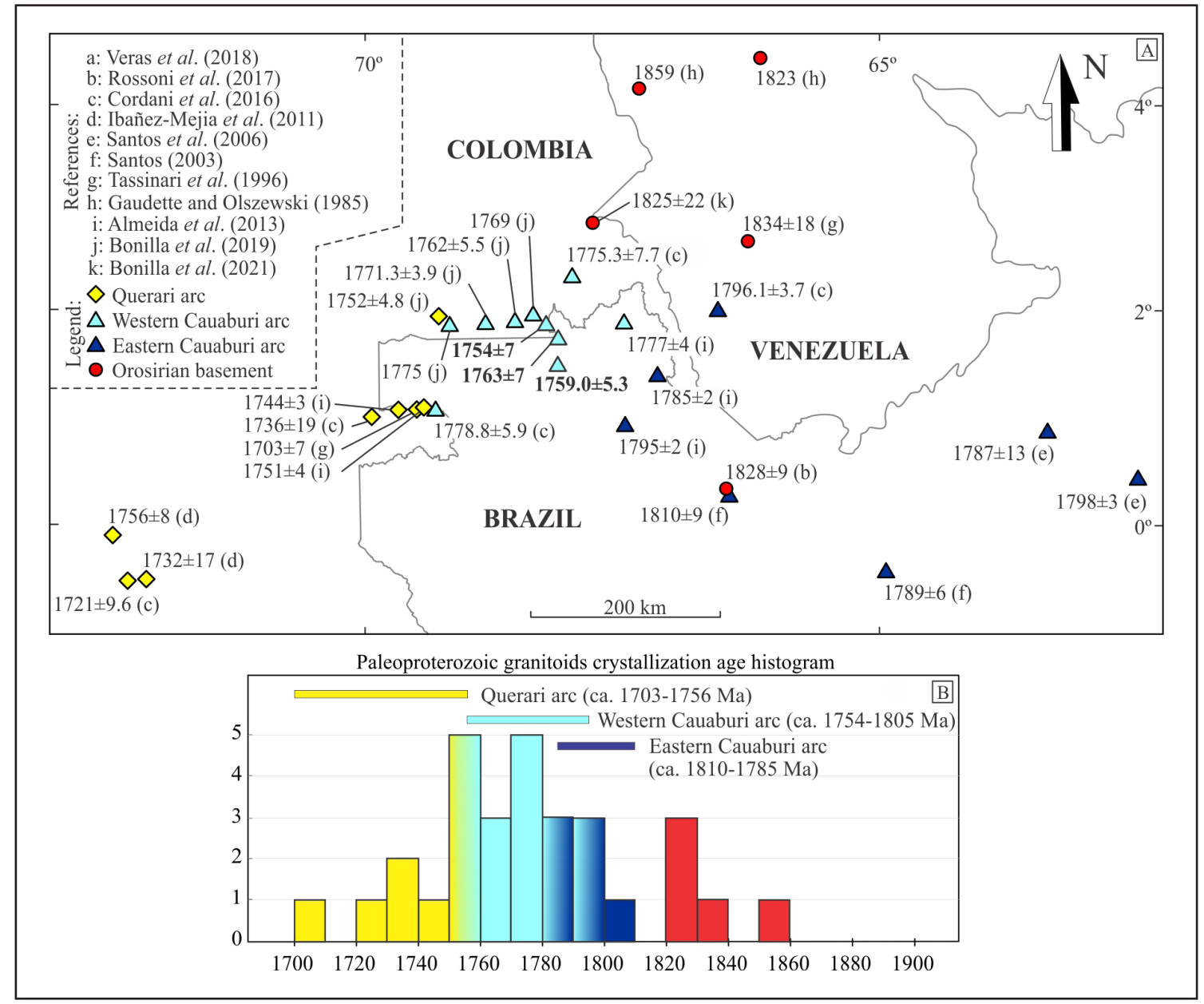

FIGURE 8. (A) Distribution of crystallization ages of Paleoproterozoic granitoids, metagranitoids, and orthogneisses of the northwestern Amazon Craton and his tectonic interpretation. The data correspond to U-Pb zircon analysis (LA-ICPMS, SIMS) and Pb-Pb zircon (evaporation), with error < $20 \mathrm{Ma}$; Gaudette and Olszewski (1985) used zircon total grain dissolution TIMS. The highlighted ages are presented in this work. (B) Histogram for the presented ages.

the remarkably complex regional geology from an incomplete puzzle. Thus, the resumption of basic geological mapping in this area carries out a great potential to bring relevant discoveries and new geological questions to further studies.

\section{Acknowledgements}

We are grateful to the researches who dared to take their boots, compasses, and hammers to this distant region of the Brazilian Amazonia, paving the geological knowledge foundations that we are currently following. We thank the Brazilian army and the local indigenous communities that allowed and assisted the field trips. We thank the JGSB editorial board and reviewers that contribute to this manuscript's improvement and publication. This research is also part of NA.19 - Pico da Neblina Project (1:1.000.000 sheet) carried out by Geological Survey of Brazil (SGB/CPRM) in partnership with the Geological Survey of Colombia.

\section{References}

Almeida F.F.M. 1981. Brazilian structural provinces: an introduction. Earth-Science Reviews, 17, 1-29. https://doi.org/10.1016/00128252(81)90003-9

Almeida M.E., Macambira M.J.B., Scheller T. 1997. Içana Intrusive Suite: age $207 \mathrm{~Pb} / 206 \mathrm{~Pb}$ (zircon evaporation) of muscovite-bearing granite,
Amazonas State, Brazil. In: South-American Symposium on Isotope Geology, 4, 31-33.

Almeida M.E., Luzardo R., Fraga L.M.B., Silva M.A., Brito M.F.L. 2000. Serra Imeri: folhas NA.20-Y/SA.20-V-A e SA.20-V-B. Escala 1:500.000. Manaus, CPRM, 93 p. Available online at: https://rigeo. cprm.gov.br/handle/doc/2564 / (accessed on 25 October 2021)

Almeida M.E., Pinheiro S.S., Luzardo R. 2002. Relatório de viagem: reconhecimento geológico ao longo dos rios Negro, Xié e lçana (Missão Tunui), noroeste do estado do Amazonas. Projeto GIS Brasil (Relatório de viagem). Manaus, CPRM, 16 p. Available online at: https://rigeo. cprm.gov.br/handle/doc/17947 / (accessed on 25 October 2021)

Almeida M.E. 2006. Província Rio Negro. In: Reis N.J., Almeida M.E., Riker S.L., Ferreira A.L. (org.). Geologia e recursos minerais do estado do Amazonas. Escala 1:1.000.000. Programa Integração, Atualização e Definição de Dados da Geologia. Manaus, CPRM, CIAMA, p. 4967. Available online at: http://rigeo.cprm.gov.br/jspui/handle/doc/2967 I (accessed on 19 April 2021)

Almeida M.E., Macambira M.J.B., Santos J.O.S., Nascimento R.S.C., Paquette J.L. 2013. Evolução crustal do noroeste do Cráton Amazônico (Amazonas, Brasil) baseada em dados de campo, geoquímicos e geocronológicos. In: Simpósio de Geologia da Amazônia, 13, 201-204. Available online at: http://arquivos.sbg-no.org.br/BASES/SGA\%2013. pdf / (accessed n 05 April 2021)

Amaral G. 1974. Geologia pré-cambriana da região amazônica. Thesis, Instituto de Geociências, Universidade de São Paulo, 212 p. https:// doi.org/10.11606/T.44.2016.tde-24062016-160651

Andretta E.R. 2020. (org.). Terras indígenas do noroeste do Amazonas: geologia, geoquímica e cadastramento mineral na região do TunuíCaparro. Manaus, CPRM, 218 p. Available online at: https://rigeo. cprm.gov.br/handle/doc/2564 / (accessed on 25 October 2021). 
Bonilla A., Cramer T., Poujol M., Cano H., Franco J.A., Amaya Z. 2019. Petrografía, geoquímica y geocronología $\mathrm{U} / \mathrm{Pb}$ en circones de rocas ígneas y metamórficas a lo largo del Río Cuiarí en el sur del Departamento de Guainía, Colombia. Boletín de Geología, 41(1), 55-84. https://doi.org/10.18273/revbol.v41n1-2019003

Bonilla A., Cramer T., De Grave J., Alessio B., Glorie S., Kroonenberg S. 2021. The NW Amazonian Craton in Guainía and Vaupés departments, Colombia: Transition between orogenic to anorogenic environments during the Paleo-Mesoproterozoic. Precambrian Research, 360, 106223. https://doi.org/10.1016/j.precamres.2021.106223

Brito M.F.L., Fraga L.M.B., Silva L.C., Santos J.O.S. 2000. Complexo Cauaburi. In: Almeida M.E., Luzardo R., Fraga L.M.B., Silva M.A., Brito M.F.L. 2000. Serra Imeri: folhas NA.20-Y/SA.20-V-A e SA.20-V-B. Escala 1:500.000. Manaus, CPRM, p. 23-27. Available online at: https:// rigeo.cprm.gov.br/handle/doc/2564 / (accessed on 25 October 2021).

Carneiro M.C.R. 2016. O Arco Magmático Cauaburi: uma revisão litoestratigráfica e sua contribuição na evolução do Domínio Imeri, Província Rio Negro, Cráton Amazônico. MSc Dissertation, Instituto de Ciências Exatas, Universidade Federal do Amazonas, 72 p. Available online at: https://tede.ufam.edu.br/handle/tede/5525 / (accessed on 25 October 2021).

Carneiro M.C.R., Nascimento R.S.C., Almeida M.E., Salazar C.A., Trindade I.R., Rodrigues V.O., Passos M.S. 2017. The Cauaburi magmatic arc: Litho-stratigraphic review and evolution of the Imeri Domain, Rio Negro Province, Amazonian Craton. Journal of South American Earth Sciences, 77, 310-326. https://doi.org/10.1016/j. jsames.2017.06.001

Cordani U.G., Tassinari C.C.G., Teixeira W., Basei M.A.S., Kawashita K. 1979. Evolução tectônica da Amazônia com base nos dados geocronológicos. In: Congreso Geologico Chileno, 2, 137-148. Available online at: https://repositorio.usp.br/item/001457566 / (accessed on 25 October 2021).

Cordani U.G., Teixeira W. 2007. Proterozoic accretionary belts in the Amazonian Craton. In: Hatcher R.D., Carlson M.P., McBride J.H., Martinez-Catalan J.R. 4-D Framework of Continental Crust. Boulder, Geological Society of America, p. 297-320. https://doi. org/10.1130/2007.1200(14)

Cordani U.G., Sato K., Sproessner W., Fernandes F.S. 2016. U-Pb zircon ages of rocks from the Amazonas Territory of Colombia and their bearing on the tectonic history of the NW sector of the Amazonian Craton. Brazilian Journal of Geology, 46, 5-35. https://doi. org/10.1590/2317-4889201620150012

Dall'Agnol R., Abreu A.S. 1976. Características petrográficas e petrológicas do Complexo Guianense na folha NA.19-Pico da Neblina. In: Congresso Brasileiro de Geologia, 29, 321-350. Available online at: http://www. sbgeo.org.br/home/pages/44 / (accessed on 25 October 2021).

Dall'Agnol R. 1992. Titanita-biotita granitos do baixo rio Uaupés, Província Rio Negro, Amazonas. Parte II: geoquímica e petrogênese. Revista Brasileira de Geociências, 22(1), 15-28. Available online at: http:// ppegeo.igc.usp.br/index.php/rbg/article/view/11709 / (accessed on 25 October 2021).

Dall'Agnol R., Macambira M.J.B. 1992. Titanita-biotita granitos do baixo rio Uaupés, Província Rio Negro, Amazonas. Parte I: geologia, petrografia e geocronologia. Revista Brasileira de Geociências, 22(1), 3-14. Available online at: http://ppegeo.igc.usp.br/index.php/rbg/ article/view/11706 / (accessed on 25 October 2021).

Fernandes P.E.C.A., Pinheiro S.S., Montalvão R.M.G., Issler R.S., Abreu A.S., Tassinari C.C.G. 1977. Geologia. In: DNPM. Folha SA.19-Içá: geologia, geomorfologia, pedologia, vegetação e uso potencial da terra. Projeto RADAMBRASIL. Rio de Janeiro, DNPM, 446 p. Available online at: https://biblioteca.ibge.gov.br/visualizacao/livros/ liv24031.pdf / (accessed on 25 October 2021).

Franzinelli E.M., Potter P. 1983. Petrology, chemistry and texture of modern river sands, Amazon river system. Journal of Geology, 91, 23-39. Available online at: http://www.jstor.org/stable/30060513/ (accessed on 25 October 2021).

Gaudette H.E., Olzewsky W.J. 1985. Geochronology of the basement rocks, Amazonas Territory, Venezuela and the tectonic evolution of the western Guiana Shield. Geologie en Mijnbouw, 64(2), 131-144.

Giovannini C.A., Larizzatti J.H. 1994. Sistemas deposicionais na Serra Acará, Amazonas. In: Congresso Brasileiro de Geologia, 38, 3, 319321. Available online at: http://www.sbgeo.org.br/home/pages/44 / (accessed on 25 October 2021).

Gomes P.J.B. 2018. Geologia do embasamento do Domínio Uaupés, Província Rio Negro, Cráton Amazônico. MSc Dissertation, Instituto de
Ciências Exatas, Universidade Federal do Amazonas, 44 p. Available online at: https://tede.ufam.edu.br/handle/tede/6531 / (accessed on 25 October 2021).

Gomes P.J.B., Nascimento R.S.C., Veras R.S., Almeida M.E., Carneiro M.C.R. 2021. Geology and geochemistry of deformed granites from the Querari Complex, Rio Negro Province, NW-Amazonian Craton, Brazil. Journal of the Geological Survey of Brazil, 4(1), 43-60. https// doi.org/10.29396/jgsb.2021.v4.n1.3

Hasui Y., Haralyi N.L., Schobbenhaus C. 1984. Elementos geofísicos e geológicos da região amazônica: subsídios para o modelo geotectônico. In: Symposium Amazônico, 2, p. 129-147.

Hilderbrand J.D., Pieren R.W., Lourenço J. 1988. Projeto Extremo Noroeste do Brasil: levantamento aeromagnéticos e aerogamaespectrométrico. Rio de Janeiro, DNPM, CPRM, 55 p. Available online at: https://rigeo. cprm.gov.br/handle/doc/8032 / (accessed on 25 October 2021).

Issler R.S., Silva G.G. 1980. The Seis Lagos carbonatite complex. In: Congresso Brasileiro de Geologia, 31, 3, 1564-1572. Available online at: http://www.sbgeo.org.br/home/pages/44 / (accessed on 25 October 2021).

Justo L.J.E.C., Souza M.M. 1986. Jazida de Nióbio do Morro dos Seis Lagos, Amazonas. In: Schobbenhaus C., Coelho C.E.S. (coord.). Principais depósitos minerais do Brasil. Brasília, DNPM, p. 463-468.

Latrubesse E.M., Franzinelli E. 1998. Late quaternary aluvial sedimentation in the Upper Rio Negro Basin, Amazonia, Brazil: palaeohydrological implications. In: Benito G., Baker V.R., Gregory K.J. Paleohydrology and environmental change. Nova Jersey, John Wiley \& Sons, p. 259-271.

Lima M.I.C., Pires J.L. 1985. Geologia da região do Alto Rio Negro - AM. In: Simpósio de Geologia da Amazônia, 2, 1, 140-154. Available online at: http://arquivos.sbg-no.org.br/BASES/Anais $\% 202 \% 20 \operatorname{Simp} \% 20$ Geol\%20Amaz\%20Dez-1985\%20Vol\%201-Belem.pdf / (accessed on 25 October 2021)

Lourenço R.S., Montalvão R.M.G., Pinheiro S.S., Fernandes P.E.C.A., Pereira E.R., Fernandes C.A.C., Teixeira W. 1978. Geologia. In: DNPM. Folha SA.20-Manaus: geologia, geomorfologia, pedologia, vegetação e uso potencial da terra. Projeto RADAMBRASIL. Rio de Janeiro, DNPM p. 17-164. Available online at: https://biblioteca.ibge. gov.br/index.php/biblioteca-catalogo?id=224035\&view=detalhes (accessed on 25 October 2021).

Luzardo R. 2000. Formação Daraá. In: Almeida M.E., Luzardo R., Fraga L.M.B., Silva M.A., Brito M.F.L. 2000. Serra Imeri: folhas NA.20-Y/ SA.20-V-A e SA.20-V-B. Escala 1:500.000. Manaus, CPRM, 93 p. Available online at: https://rigeo.cprm.gov.br/handle/doc/2564 / (accessed on 25 October 2021)

Melo A.F.F., Santos C.A., Villas Boas P.F. 1993. Geologia da região das Serras Aracá e Daraá, nordeste do Estado do Amazonas (relatório interno). Manaus, CPRM.

Melo A.F.F., Villas Boas P.F. 1993. Projeto Alto Rio Negro (relatório preliminar). Manaus, CPRM.

Melo A.F.F., Villas Boas P.F. 1994. Geologia da região do Alto Rio Negro - setor noroeste do estado do Amazonas. In: Simpósio de Geologia da Amazônia, 4, 22-25. Available online at: http://sbg.sitepessoal.com/ anais digitalizados/nucleonorte/Anais $\% 204 \% 20 \mathrm{Simp} \% 20 \mathrm{Geol} \% 20$ Amaz\%20Junho-1994\%20Vol\%201-Belem.pdf / (accessed on 25 October 2021).

Melo A.F.F., Santos C. A., Villas Boas P.F., João X.S.J. 1996. O Cinturão de cisalhamento Guiana Central na região noroeste do estado do Amazonas - Projeto Alto Rio Negro. In: Simpósio de Geologia da Amazônia, 5, 301-303. Available online at: http://sbg.sitepessoal. com/anais digitalizados/nucleonorte/Anais $\% 205 \% 20$ Simposio $\% 20$ Geol\%20Amazonia\%20Junho-1996-Belem.pdf / (accessed on 25 October 2021).

Mendes T.A.A., Mesquita R.B., Almeida M.E. 2020. Mapa geológico: área Tunuí-Caparro: folhas NA.19-Z-A-II, NA.19-Z-A-V e NA.19-ZA-VI. Projeto Terras Indígenas do Noroeste do Amazonas. Escala 1:250.000. Manaus, CPRM. Available online at: https://rigeo.cprm.gov. br/handle/doc/21745 / (accessed on 25 October 2021).

Mendes T.A.A., Mesquita R.B., Knauer L.G., Almeida M.E., Roncato J. 2021. Spatiotemporal constraints on the western Cauaburi Belt tectonics - northwestern Amazon Craton, Brazil. International Geology Review, 63(11), 1342-1365. https://doi.org/10.1080/0020681 4.2020.1768441

Montalvão R.G.M., Muniz C.M., Issler R.S., Dall’Agnol R., Lima M.I.C., Fernandes P.E.C.A., Silva G.G. 1975. Geologia. In: DNPM. Folha NA.20-Boa Vista e parte das folhas NA.21-Tumucumaque, NB.20- 
Roraima e NB.21. Projeto RADAMBRASIL. Rio de Janeiro, DNPM. Available online at: https://biblioteca.ibge.gov.br/index.php/bibliotecacatalogo?view=detalhes\&id $=23587 /$ ( accessed on 25 October 2021).

Paiva G. 1929. Reconhecimentos geológicos nas fronteiras do Brasil com a Venezuela e Colômbia. Rio de Janeiro, Serviço Geológico e Mineralógico do Brasil, p. 15-21.

Pinheiro S.S., Fernandes P.E.C.A., Pereira E.R., Vasconcelos E.G., Pinto A.C., Montalvão R.M.G., Issler R.S., Dall'Agnol R., Teixeira W., Fernandes C.A.C. 1976. Geologia. In: DNPM. Folha NA.19 Pico da Neblina: geologia, geomorfologia, pedologia, vegetação e uso potencial da terra. Projeto RADAMBRASIL. Rio de Janeiro, $380 \mathrm{p}$. Available online at: https://biblioteca.ibge.gov.br/index.php/bibliotecacatalogo? view=detalhes \&id=281384 / (accessed on 25 October 2021).

Rodrigues V.O. 2016. Evolução petrogenética e metamorfismo das rochas ortoderivadas da Litofácies Tarsira no perfil entre São Gabriel da Cachoeira e Cucuí-Amazonas. MSc Dissertation, Instituto de Ciências Exatas, Universidade Federal do Amazonas, 65 p. Available online at: https://tede.ufam.edu.br/handle/tede/5501 / (accessed on 25 October 2021).

Rossoni M.R., Bastos Neto A.C., Saldanha D.L., Souza V.S., Giovannini A.L., Porto C.G. 2016. Aplicação de técnicas de sensoriamento remoto na investigação do controle do posicionamento do Complexo Carbonatítico Seis Lagos e no estudo do depósito $(\mathrm{Nb})$ laterítico associado (Amazonas, Brasil). Pesquisas em Geociências, 43(2), 111125. https://doi.org/10.22456/1807-9806.78196

Rossoni M.R., Bastos Neto A.C., Souza V.S., Marques J.C., Dantas E., Botelho N.F., Giovannini A.L., Pereira V.P. 2017. U-Pb zircon geochronologycal investigation on the Morro dos Seis Lagos Carbonatite Complex and associated Nb deposit (Amazonas, Brazil). Journal of South American Earth Sciences, 80, 1-17. https://doi. org/10.1016/j.jsames.2017.09.021

Santos J.O.S., Nelson B.W. 1995. Os campos de dunas do Pantanal Setentrional. In: Congresso Latino-Americano de Geologia, 8, Ministerio de Energía y Minas.

Santos J.O.S., Hartmann L.A., Gaudette H.E., Groves D.I., McNaughton N.J., Fletcher I.R. 2000. A new understanding of the provinces of the Amazon Craton based on integration of field mapping and $\mathrm{U}-\mathrm{Pb}$ and Sm-Nd geochronology. Gondwana Research, 3(4), 453-488. https:// doi.org/10.1016/S1342-937X(05)70755-3

Santos J.O.S., Hartmann L.A., McNaughton N.J., Fletcher I.R. 2002. Timing of mafic magmatism in the Tapajós Province (Brazil) and implications for the evolution of the Amazon craton: evidence from baddeleyite and zircon U-Pb SHRIMP geochronology. Journal of South American Earth Sciences, 15(4), 409-429. https://doi.org/10.1016/ S0895-9811(02)00061-5

Santos J.O.S. 2003. Geotectônica dos Escudos das Guianas e BrasilCentral. In: Bizzi L.A., Schobbenhaus C., Vidotti R.M., Gonçalves J.H. 2003. Geologia, tectônica e recursos minerais do Brasil: texto, mapas e SIG. Escala 1:2.500.000. Brasília, CPRM, 169-226.

Santos J.O.S., Hartmann L.A., Faria M.S.G., Riker S.R.L., Souza M.M., Almeida M.E. 2006. A compartimentação do Cráton Amazonas em províncias: avanços ocorridos no período 2002-2006. In: Simpósio de Geologia da Amazônia, 9, 156-159.

Santos J.O.S., Rizzotto G.J., Potter P.E., McNaughton N.J., Matos R.S., Hartmann L.A., Chemale F., Quadros M.E.S. 2008. Age and autochthonous evolution of the Sunsás Orogen in West Amazon Craton based on mapping and $\mathrm{U}-\mathrm{Pb}$ geochronology. Precambrian Research, 165(3-4), 120-152. https://doi.org/10.1016/j.precamres.2008.06.009

Souza A.G.H. 2009. Petrografia e geoquímica do Batólito Granítico São Gabriel da Cachoeira, Província Rio Negro (AM). MSc Dissertation, Instituto de Ciências Exatas, Universidade Federal do Amazonas, 89 p. Available online at: https://rigeo.cprm.gov.br/handle/doc/379 / (accessed on 25 October 2021).

Tassinari C.C.G. 1981. Evolução geotectônica da província Rio NegroJurena na região amazônica. MSc Dissertation, Instituto de Geociências, Universidade de São Paulo, 101 p. https://doi.org/10.11606/D.44.1981. tde-11062013-163626

Tassinari C.C.G. 1996. O mapa geocronológico do Cráton Amazônico no Brasil: revisão dos dados isotópicos. Thesis, Instituto de Geociências, Universidade de São Paulo, 129 p. https://doi.org/10.11606/T.44.2013. tde-22082013-163642

Tassinari C.C.G., Cordani U.G., Nutman A.P., Schmus W.R.V., Bettencourt J.S., Taylor P.N. 1996. Geochronological systematics on basement Rocks from the Rio Negro-Juruena Province (Amazonian Craton) and tectonic implications. International Geology Review, 38(2), 161-175. https://doi.org/10.1080/00206819709465329

Tassinari C.C.G., Macambira M.J.B. 1999. Geochronological provinces of the Amazonian Craton. Episodes, 22(3), 174-182. https://doi. org/10.18814/epiiugs/1999/v22i3/004

Tassinari C.C.G., Macambira M.J.B. 2004. A evolução tectônica do Cráton Amazônico. In: Mantesso Neto, V., Bartorelli, A., Carneiro, C.D.R., Neves, B.B.B. O desvendar de um continente: a moderna geologia da América do Sul e o legado da obra de Fernando Flávio Marques de Almeida. São Paulo: Beca, p. 471-486.

Teixeira W., Tassinari C.C.G., Cordani U.G., Kawashita K. 1989. A review of the geochronology of the Amazonian Craton: tectonic implications. Precambrian Research, 42(3-4), 213-227. https://doi. org/10.1016/0301-9268(89)90012-0

Veras R.S. 2012. Petrologia de granitóides dos arredores da Missão Tunuí, NW do Amazonas, Província Rio Negro, Cráton Amazônico. MSc Dissertation, Instituto de Ciências Exatas, Universidade Federal do Amazonas, 110 p. Available online at: https://tede.ufam.edu.br/ handle/tede/4661 / (accessed on 25 October 2021).

Veras R.S., Nascimento R.S.C., Almeida M.E., Paquette J.L., Carneiro M.C.R. 2018. Paleoproterozoic basement of Içana Domain, Rio Negro Province, northwestern Amazonian Craton: Geology, geochemistry and geochronology (U-Pb and Sm-Nd). Journal of South American Earth Sciences, 86, 384-409. https://doi.org/10.1016/j.jsames.2018.07.003

Veras R.S., Macambira M.J.B., Nascimento R.S.C., Almeida M.E. 2019. Registro geocronológico da Orogenia Içana em rochas do Complexo Cauaburi - Fácies Tarsira, noroeste do Amazonas. In: Simpósio de Geologia da Amazônia, 16, 675-678. Available online at: http://sbg. sitepessoal.com/anais digitalizados/simposioamazonas/ANAIS 16 Simposio_Geologia_da_Amazonia.pdf / (accessed on 25 October 2021).

Viegas Filho J.R., Bonow C.W. 1976. Projeto Seis Lagos: relatório final. Manaus, CPRM. Available online at: https://rigeo.cprm.gov.br/handle/ doc/7601 / (accessed on 25 October 2021).

Wallace A.R. 1853. A narrative of travels on the Amazon and Rio Negro, with an account of the native tribes, and observations on the climate, geology, and natural history of the Amazon Valley. London, Reeve \& Co, 541 p. https://doi.org/10.1017/CBO9780511695476 